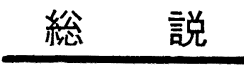

\title{
魚の必要脂肪酸と種苗生産
} 渡辺武

東京水産大学水産養殖学科 (港区港南 4-5-7)

\section{Nutritional Quality of Live Foods Used in the Seed Production of Fish from the View-point of Essential Fatty Acids}

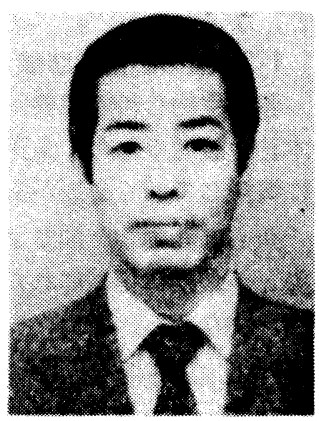

Takeshi WATANABE

Laboratory of Fish Nutrition, Tokyo University of Fisheries (Konan 4, Minato-ku, Tokyo)

\section{1 はじめに}

近年, 魚類の種苗生産*における技術面での進歩は著 しく, 種苗生産対象魚種は年々増加しつつある。しか し, その基礎研究は, 種苗の初期減耗の例でみられるよ うに, し(仔)稚魚の栄養要求や生物し(䬣)料の栄養価に 関する研究注かなり遅れた。最近，し(仔)稚魚用生物し 料の栄養価に関して, タンパク質 ${ }^{1)}$, ミネラル22), ビタ

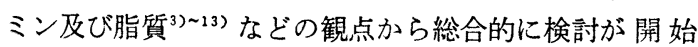
され，いくつかの問題点が明らかにされた。ここでは本 総説の趣旨から脂質にしぼって, 特に最近急速に進展し た魚類の必要脂肪酸 (EFA) の観点から, 種苗生産用生 物し料及びその栄養価改善法について論じてみたい。な お，脂質以外の成分については最近発刊された「魚類の 栄養と飼料」(荻野珍吉編) ${ }^{14}$ )を参照されたい。

\section{$1 \cdot 1$ し料系列における問題点}

現在, ふ化し魚用の人工配合飼料は完成されておら ずほほとんどすべてのふ化し魚の飼育には生物し料が使 用されている。各地の種苗生産の現場で採用され, ほと んどすべての海産魚の種苗生産に通用するし料系列を模 式的に示したのが図-1である。ふ化し魚が $2.3 \mathrm{~mm}$ 以 上の魚においては，最初のえさをしおみずっぼわむし

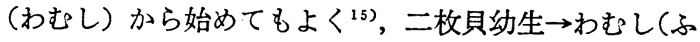
化後 $4 \mathrm{~d}$ から $30 \mathrm{~d}) \rightarrow$ 甲款類プランクトン (13〜18 d か ら $35 \mathrm{~d}) \rightarrow$ 魚介肉ミンチ $(15 \sim 25 \mathrm{~d}$ 以後終了まで) が確

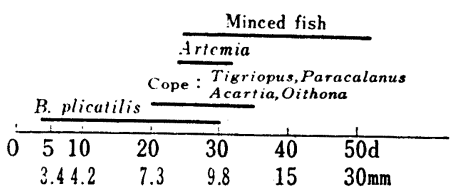

図-1 乙料系列の模式図

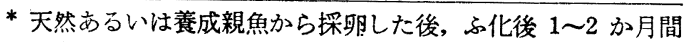
飼育し, 体長数 $\mathrm{cm}$ の稚魚を生産することをいう。生産され た種苗は放流あるいは養殖に用いられる。
立されている。ここで最も多用されているのが袋形動物 門，輪虫綱に属する体長 80〜350 菂のわむしであり， 初期し料に適していることが見いだされて以来，乙稚魚 の飼育技術は飛躍的な進歩をとげたといわれている。わ むしは従来海産クロレラ chlorella sp. をし料として培 養されていたが，10年程前に酵母類がその培養し料とし て優れていることが明らかにされ(6) 18), 種 苗生産の大 量化に対応してわむしの培養に酵母を使用することが普 及した15)。

ところが，酵母で培養したわむしで飼育したし稚魚は 刺激への反応が緩慢となり，腹部が著しく膨満する例や 著しい場合には給じ（餌）開始後 $10 \mathrm{~d}$ 前後で全滅する 例がまだい(19,20) やいしだい21),22)などで多数報告され た。これを䂆防するにはわむしの培養に当たりえさとし て酵母とクロレラの併用，または給じ前にわむしにクロ レラを捸取させるなどの方法が有効とされており，“ク ロレラ処理”などと称されている。

つぎにわむしでし魚後期末まで飼育された変態期前後 の稚魚を, 魚介肉ミンチにえ付けさせる時期に甲殸類プ ランクトンが与えられるが，このときアルテミア幼生 (ブライン・シュリンプ) が補助的に使用されている。 しかし，アルテミア幼生を単独に連続給じすると多くの 魚で大量へい死が起こり ${ }^{22)}$ ，へい死しないものも活力が 低下し，またこの現象は魚種によって差異があるといわ れている。この原因としては, 残存農薬, 消化不良, 栄 養欠陥などがあげられている。

このほか, 異質の問題として, このし料系列には生物 し料の大量培養または採集上の問題点がある。たとえ ば, $10 \mathrm{~mm}$ サイズのまだい 100 万尾を生産しようとす れば，ピーク時には 1 日 50 億個程度のわむし（わむし 1 個体が約 $3 r$ ) を必要とするが, この生産には粗放培 美では $200 \mathrm{t}$ 槽 4 基程度を必要とし, かつわむしの増殖 のピークと需要のピークを一致させることが難しいこ と, 甲款類プランクトンの採集が量的に追いつかないこ 


\section{となどがある(5)。}

\section{2 魚の必要脂肪酸}

各種生物し料の栄養価をEFAの観点から論ずる前に, 本誌の読者のために魚類の EFA 要求についてごく簡単 に概説しておく必要があろう。

魚もほ乳動物と同じようにある種の EFA を要求する ことが最初に指摘されたのはかなり以前のことである 25)。すなわち，アセタート $-1-{ }^{14} \mathrm{C}$ がリノール酸（18: $2 \omega 6) *$ 一ほとんど取り込まれないことから，18:2 266 は魚類によって合成されず，魚にとっても EFA である うと考えられた。また魚の肝臟スライスによるアセター ト $-1-^{14} \mathrm{C}$ からの脂肪酸合成をみた実験で, 魚類におけ る $\mathrm{C}_{20}$ 及び $\mathrm{C}_{22}$ ポリエン酸は外因性の親酸から 導かれ ることが示された。

これらの脂肪酸代謝に関する研究とは別に, 飼育実験 によっても魚の EFA の必要性が検討され，ますのすけ 稚魚では $18: 2 \omega 6$ 欠泛により成長阻害と皮膚の退色が 起こるが, リノレン酸 $(18: 3 \omega 3)$ 久乏では成長低下の みが起こり，18:3 33 は体色に関与しないことが報告 された24)。一方，にじますでも無脂肪飼料による成長低 下に対して, 高度不飽和酸 $>18: 3 \omega 3>18: 2 \omega 6$ の順 でその添加効果が認められている ${ }^{25}$ 。このように, 魚も EFA を要求することは古くからわかっていたが，その 要求量や魚種による EFA 要求の違いが明らかにされた のはごく最近のことである。

魚類で最初に EFA の要求量や欠乏症が明らかにされ

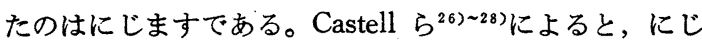
ますを EFA 欠乏飼料で飼育すると成長が劣り, 飼料効 率が低く，さらに久乏症として，ひれ（鱛）のびらん， 心筋の炎症，生理的食塩水中でのミトコンドリアの膨潤 度の增加, 血液へモグロビン含量の低下及び筋肉水分含 量の増加などが起こる。そして飼育魚の成長の改善や， 欠乏症発生の防止に対しては, $18: 2 \omega 6$ よりも $18: 3$ $\omega 3$ の方が優れていたことから，にじますにおいては人 や高等動物で $18: 2 \omega 6$ が 果たすとしている重要な役割 を $18: 3 \omega 3$ が果たすものと結論している。

渡辺ら ${ }^{29) \sim 31)}$ もにじますについて Castell らとほぼ同 様の結論を得るとともに, EFA 要求量は飼料中の脂質 含量によって左右されることを明らかにした ${ }^{32)}$ 。さらに 後の実験で, 肝油などに含まれる $\mathrm{C}_{20}$ 以上の $\omega 3$ 高度不 飽和酸 $(20: 5 \omega 3,22: 6 \omega 3$ など) ( $\omega 3$ HUFA) は, $18: 3 \omega 3$ よりも 2 倍以上の $\mathrm{EFA}$ 力価を有することを 明らかにした ${ }^{33) \sim 35) 。 ~}$

一方, こいの EFA 要求量はにじますよりもかなり低

* 不飽和脂肪酸の二重結合の位置を表示する場合, 本総説など の分野ではメチル基 ( $\omega$ 位) の炭素から番号をつける表示法 が一般的である。この表示法では, オレイン酸は $18: 1 \omega 9$, リノール酸は, $18: 2 \omega 6$, リノレン酸は $18: 3 \omega 3$ となる。
く，ある程度成長したこいでは $\mathrm{EFA}$ 欠乏はほとんど出 現しない ${ }^{36)}$ 。また EFA 欠乏飼料に $18: 2 \omega 6$ あるいは $18: 3 \omega 3$ を添加すると, 成長がかなり改善されるが, 両者を併用した方が，より優れた成長が得られ ${ }^{37}$ ，こい の両脂肪酸に対する要求量は飼料中各 $1 \%$ であることが わかった ${ }^{38}$ 。

うなぎは, $18: 3 \omega 3$ 添加により成長が著しく改善さ れる点はにじますに似ているが, $18: 2 \omega 6$ と $18: 3 \omega 3$ の付加効果 (additive effect) が認められる点はこいに似 ている。両脂肪酸に対する要求量は飼料中各 $0.5 \%$ 前後 であった。

最近, 養殖生産量が増加しつつあるティラピアの $\mathrm{EFA}$ は他の魚とはかなり異なることがわかった。すなわち， $18: 3 \omega 3$ を含めて $\omega 3$ 脂肪酸には $\mathrm{EFA}$ としての効果 がみられず，18:2 $\omega 6$ が EFA として優れた成長促進 効果を有することがわかっだ(0),41)。高等動物の EFA 要 求と似ている。

また最近, 淡水及び海水中におけるしろざけの $\mathrm{EFA}$ 要求も明らかにされた ${ }^{(2), 43)}$ 。スモルト化**による EFA 要求の変化はないようで, いずれの環境においても $18: 3$ $\omega 3$ あるいは $\omega 3$ HUFA の添加によって成長が著しく 改善される点はにじますに似ており, $18: 2 \omega 6$ と 18 : $3 \omega 3$ の付加効果が認められる点は上記のこいやうなぎ に似ている。最大成長に必要な EFA の要求量は, 18 : $2 \omega 6$ 及び $18: 3 \omega 3$ を各 $1 \%, \omega 3$ HUFA ならば 0.5 〜1\% である。これはこいやにじますの EFA 要求量に 匹敵するものである。

なお，あゆの EFA 要求についてはまだ明確ではない が，添加脂肪酸の体脂質脂肪酸組成へ及ぼす影響をみる と, 他の淡水魚と同じ脂肪酸代謝経路をもつことがわか る $^{44), 45}($ 表-1)。また, あゆのし稚魚用生物し料として用 いているわむしに $\omega 3$ HUFA を取り込ませると, わむ しの飼料効率あるいは栄養価が著しく改善される ${ }^{12), 13), ~}$ 16)ことから，あゆもにじますに似た EFA 要求をするも のと推察される。

一方, 海水魚が陸上動物あるいは上記の淡水魚のいず れとも異なった EFA 要求をもつことが, 最近の研究に

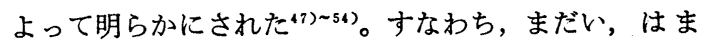
ち, ひらめ ${ }^{55}$ などでは $18: 2 \omega 6$ や $18: 3 \omega 3$ が EFA としての効果をもたず，いずれも $20: 5 \omega 3$ や $22: 6 \omega 3$ などの $\omega 3 \mathrm{HUFA}$ を $\mathrm{EFA}$ として要求することがわか った。また淡水魚で EFA として重要な役割をもつ18： $3 \omega 3$ を $4 \%$ まで飼料に添加してもまだいでは効果がな く，逆に脂肪肝をひき起こすことが報告されている47)。

** 河川でふ化したさけ・立類の稚魚は，ある期間淡水で生活 した後降海するが，この时期になると体表が銀色になる銀毛 体（スモルト）となり, 魚体の生理条件に多くの変化汸現 れ，海水適応の機能が発達する。この現象をいう。 
变-1 淡水魚の肝臟（肝すい臓）極性脂質の脂肪酸組成に及ぼす飼料脂質の影響（％）

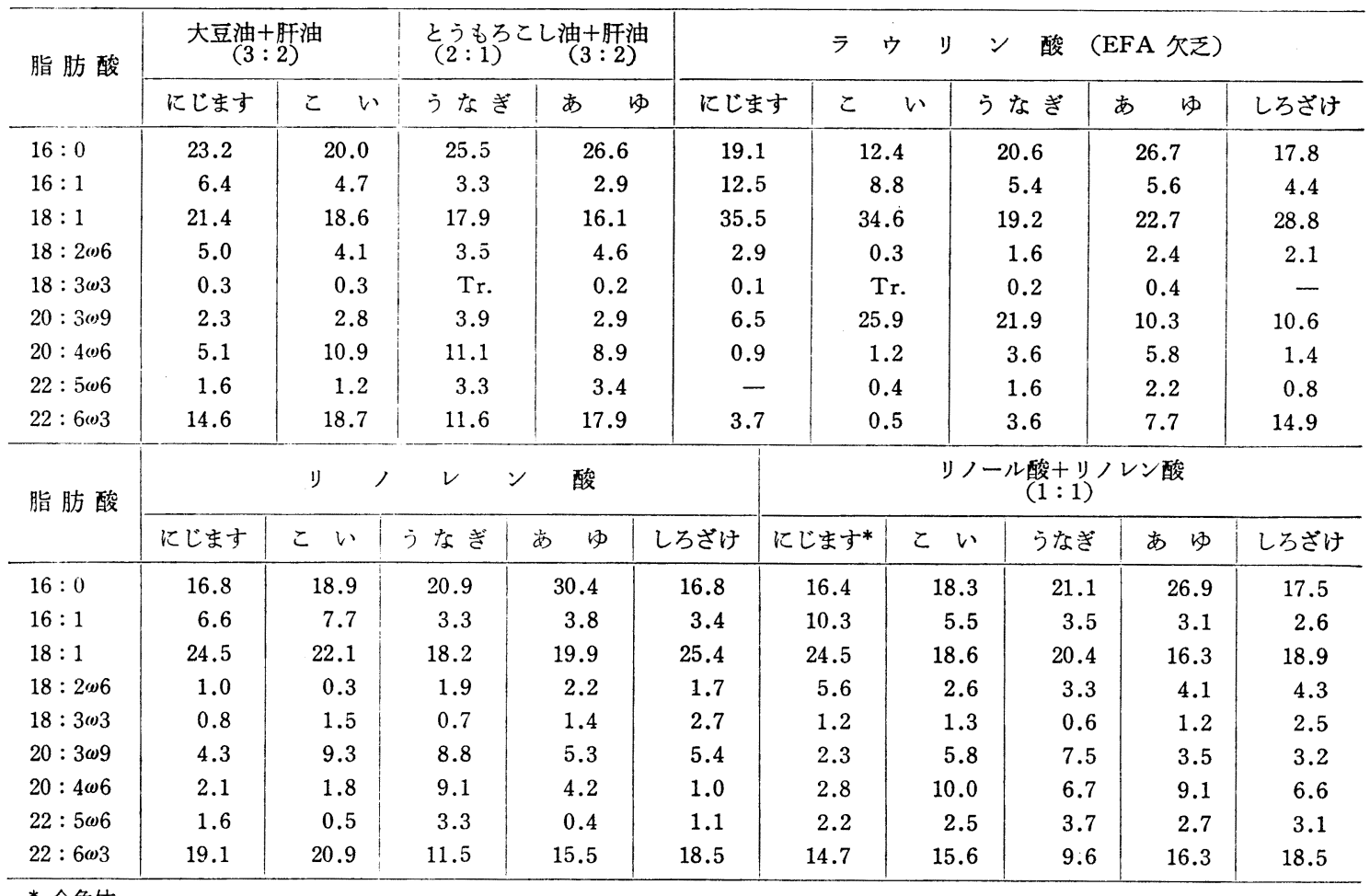

* 全魚体

このように海水魚では淡水魚の EFA である $18: 2 \omega 6$ や $18: 3 \omega 3$ は成長促進効果がなく, $\omega 3$ HUFA を必要 とし, 両者の間では EFA 要求が大きく相違し, 同じ淡 水魚あるいは海水魚でも魚種によって多少異なることが 明らかにされた。淡水魚と海水魚の EFA 要求の相違の 原因として，両魚種における脂肪酸代謝の相違が考えら れている。淡水魚では表-1 に示したように, $18: 3 \omega 3$ は $\omega 3$ HUFA（最終 $\omega 3$ 脂肪酸は $22: 6 \omega 3$ ) に転換さ れるが，まだいなどでは $18: 3 \omega 3$ から $20: 5 \omega 3$ や $22: 6 \omega 3$ などの $\omega 3$ HUFA に転換する能力が低いため と推測されている。

最近，その推測を裏付ける研究がアイソトープを用い

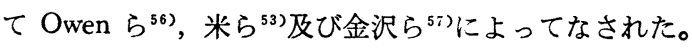

以上述べたことから, 海水魚は主に $\omega 3$ HUFA を $\mathrm{EFA}$ 上して要求し, 淡水魚の EFA である $18: 2 \omega 6$ や $18: 3 \omega 3$ は EFA としての働きをもたないこと, ま た $\omega 3$ HUFA は逆にほとんどすべての魚にとって EFA 力価を有するといらことがおわかり頂けたかと思う。

このような魚の EFA 要求に基ゔいて, 種苗生産用生 物し料の栄荃価をみてみたい。

\section{2 しおみずつぼわむし Brachionus plicatilis}

\section{$2 \cdot 1$ 海産クロレラで培粱したわむし}

パン酵母 Saccharomyces cerevisiae の使用によって わむしの量産が容易になり，また方法が簡便化された が，醭母単用によるわむし（酵母わむし）でし稚魚を飼 育すると, 虚弱で大量へい死する事例が多いので, 実際 には給じ前にクロレラで二次培垗するか，あるいはク口

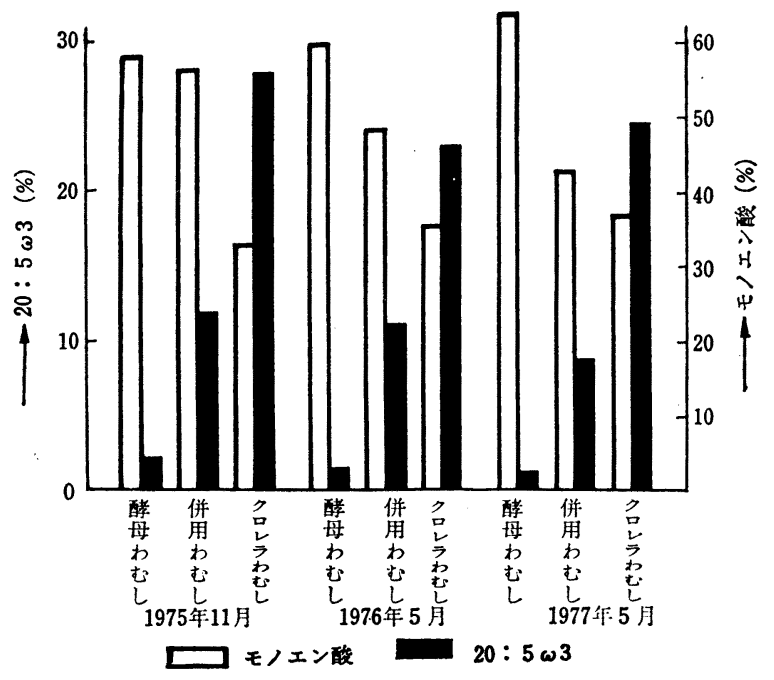

図-2 長崎水試増養研で培養した酵母わむし，併用わむし及 びクロレラわむしのモノエン酸及び $20: 5 \omega 3$ の含量 
レラと酵母の併用給じによって培養したわむし（併用わ むし）が使用されている。

長崎県水産試験場増養殖研究所 (長崎水試)で 1975 1977 年に培養した各わむしの総脂質のモノエン酸及び $20: 5 \omega 3$ 含量を 图-2 に示した ${ }^{13)}$ 。各わむしの培養条 件や時期は年によって多少異なるが，その組成に同じ傾 向がみられる。酵母わむしでは，モノェン酸含量が高く $20: 5 \omega 3$ のような $\omega 3$ HUFA の割合が低く，魚類の EFA 欠乏の状態と大変よく似ている。一方クロレラわ むしでは逆にモノエン酸含量が低く, $20: 5 \omega 3$ の割合 が著しく高く, 酵母わむしの 1 2\% に対して，20２8 \%も含まれている。併用わむしはほぼその中間の值であ る。ここでわむし中の $20: 5 \omega 3$ の含量が問題となるの は，前述したように $20: 5 \omega 3$ が $22: 6 \omega 3$ と並んでま だいをはじめ海水魚の EFA であるからである。酵母わ もしのように $\omega 3$ HUFA のみならず，淡水魚の EFA である $18: 3 \omega 3$ をも含まないし料は, まだいなどの海 水魚に限らず，淡水魚にとっても栄養価が低いといえよ う。このように酵母わむしとクロレラわむしの脂肪酸組 成では, $20: 5 \omega 3$ の含量に顕著な相違があることが明 らかにされた。渡辺ら ${ }^{3}$ は, この $\omega 3$ HUFA 含量の差が 両わむしの栄養価を左右している主要因であり，酵母わ むしを海産クロレラで二次培養すると栄養価が改善され るのも, 二次培養によってクロレラから $20: 5 \omega 3$ を取 り込むためと推察している。このことはまた，両わむし の中間の $20: 5 \omega 3$ 含量をもつ併用わむしで, まだい, いしだいなどの種苗の量産が行われていることからもう かがわれるとしている。

\section{$2 \cdot 2$ 淡水クロレラで培褰したわむし}

岐阜県水産試験場で培羲した醭母わむし，あゆに給じ する前に酵母わむしを淡水クロレラで二次培養したクロ レラわむしならびにパン酵母と光合成細菌の併用で培養 したわむしの脂肪酸組成の一部を 表-2 に示した ${ }^{3)}$ 。酵 母わむしとクロレラわむしの脂肪酸組成には培養年度に よる差が多少あるが，両わむしには同じ傾向がみられ る。酵母わむしは長崎水試のものと非常によく似た組成 を示し，モノエン酸含量が高く, $\omega 3$ HUFA の含量が非 常に低い。このようにパン酵母で培養したわむしはいず れの場合も魚類に対する EFAの含量が低く, 栄養価の 低、生物し料といえよう。この醉母わむしを淡水クロレ ラで二次培養すると，モノエン酸の割合が減少し，18： $2 \omega 6$ 及び $18: 3 \omega 3$ の割合が著しく増加したが, 海産 クロレラによる場合と異なり, $\omega 3$ HUFA の增加仗認め られない。同じクロレラでも海産と淡水産クロレラを用 いた場合とでは，わむしの脂肪酸組成は大きく異なり， 淡水クロレラで培養したわむしはあゆなどの淡水魚に対 してはともかくとして, まだいなどの海産魚に対しては し料効果が低いといえよう。

なお，パン酵母と光合成細菌の併用で培養したわむし では, $18: 2 \omega 6$ の含量が著しく高く, $\omega 3$ 脂肪酸含量 が低いので，いずれの魚種に対しても栄養価は低いもの と考えられる。

\section{$2 \cdot 3$ 培㩊し料の脂肪酸組成}

各わむしでみられた脂肪酸組成の相違は，培養に用い たし料, パン酵母, 海産クロレラ, 及び淡水クロレラの 脂肪酸組成の相違によるものである。

表-2 岐阜水試でパン酵母及び淡水クロレラを用いて培養した各わむし，ならびに酵母と光合成細菌の 併用で培養したわむしの各脂質画分の脂肪酸組成の一部

\begin{tabular}{|c|c|c|c|c|c|c|c|c|c|c|}
\hline \multirow{3}{*}{ 脂肪 酸 } & \multicolumn{6}{|c|}{11 月 1975} & \multicolumn{4}{|c|}{1976 総 脂 澌 } \\
\hline & 総 & 質 & \multicolumn{2}{|c|}{ 極 性 脂 質 } & \multicolumn{2}{|c|}{ トリグリセリド } & \multirow{2}{*}{$\begin{array}{cc}8 & \text { 月 } \\
\text { 酵母わむし }\end{array}$} & \multicolumn{2}{|c|}{ クロレラわむし } & \multirow{2}{*}{$\begin{array}{c}8 \text { 月 } \\
\text { パソ酵母+ } \\
\text { 光合成細菌 }\end{array}$} \\
\hline & 酵母わむし & $\begin{array}{l}\text { クロレラ } \\
\text { わむし }\end{array}$ & 酵母わむし & $\begin{array}{l}\text { クロレラ } \\
\text { わむし }\end{array}$ & 酵母わむし & $\begin{array}{l}\text { クロレラ } \\
\text { わすらし }\end{array}$ & & I & II & \\
\hline $14: 0$ & 2.8 & 4.6 & 2.4 & 1.5 & 3.1 & 3.0 & 2.7 & 3.2 & 1.5 & 1.0 \\
\hline $16: 0$ & 6.7 & 8.9 & 10.3 & 11.7 & 7.1 & 9.9 & 6.8 & 9.3 & 9.9 & 9.6 \\
\hline $16: 1 \omega 7$ & 23.4 & 18.9 & 16.9 & 10.7 & 22.9 & 12.4 & 21.3 & 14.7 & 13.7 & 4.4 \\
\hline $16: 4 \omega 3$ & - & 3.9 & - & 0.6 & $\operatorname{Tr}$. & 0.9 & - & 0.2 & 2.2 & 0.7 \\
\hline $18: 0$ & 5.6 & 1.6 & 6.7 & 6.1 & 7.0 & 9.0 & 5.3 & 5.1 & 4.2 & 4.8 \\
\hline $18: 1 \omega 9$ & 31.2 & 9.0 & 28.4 & 20.1 & 28.5 & 27.4 & 36.2 & 22.4 & 24.4 & 17.0 \\
\hline $18: 2 \omega 6$ & 5.9 & 15.7 & 5.9 & 18.0 & 3.9 & 12.9 & 5.9 & 18.5 & 19.3 & 36.5 \\
\hline $18: 3 \omega 3$ & 0.6 & 10.2 & 1.9 & 5.1 & 0.4 & 1.7 & 1.2 & 3.7 & 7.7 & 2.1 \\
\hline $20: 1$ & 0.6 & 0.3 & 5.4 & 8.3 & 3.7 & 4.8 & 4.9 & 3.4 & 2.9 & 3.0 \\
\hline $\left.\begin{array}{l}20: 3 \omega 3 \\
20: 4 \omega 6\end{array}\right\}$ & 1.3 & 0.8 & 1.1 & 2.0 & 2.0 & 1.5 & 0.6 & 1.0 & 1.2 & 1.7 \\
\hline $20: 4 \omega 3$ & 0.4 & 1.1 & 0.5 & 1.3 & 0.2 & 0.5 & 0.6 & 1.1 & 0.1 & Tr. \\
\hline $20: 5 \omega 3$ & 2.0 & 1.9 & 3.5 & 2.1 & 1.6 & - & 30 & 19 & 12 & 15 \\
\hline $22: 1$ & 1.0 & 4.1 & 1.3 & 2.8 & 2.2 & - & 2.0 & 1.9 & 1.2 & 1.0 \\
\hline $22: 5 \omega 3$ & - & 0.3 & - & 0.4 & 0.2 & - & 1.1 & 0.2 & 0.6 & 0.6 \\
\hline $22: 6 \omega 3$ & 1.0 & - & 0.5 & Tr. & 0.5 & - & - & - & - & - \\
\hline
\end{tabular}


表-3 パン酵母及び海産クロレラの総脂兵の脂肪酸組成

\begin{tabular}{|c|c|c|c|c|c|c|c|c|c|c|}
\hline \multirow{3}{*}{ 脂 肪 酸 } & \multicolumn{4}{|c|}{ ハシソ酵母 Saccharomyces cerevisiae } & \multicolumn{2}{|c|}{ 海 産 } & D & \multicolumn{2}{|l|}{ レ $\quad$ ラ } & \multirow{3}{*}{$\begin{array}{l}\text { 熊本水試 } \\
\text { Nano } \\
\text { nochloris } \\
\text { coccoides } \\
\text { Nauman } \\
11 \text { 月 } 1978 \\
\end{array}$} \\
\hline & \multicolumn{2}{|c|}{ 力 兵 } & \multirow{2}{*}{$\begin{array}{l}\text { 協 和 } \\
1977\end{array}$} & \multirow{2}{*}{$\begin{array}{c}\text { オリエソ } \\
\text { タル } \\
1977\end{array}$} & \multicolumn{2}{|c|}{$\begin{array}{l}\text { 長崎水試 Chlorella } \\
\text { minutissim }\end{array}$} & \multirow{2}{*}{$\begin{array}{l}\text { 山口外海 } \\
\text { 水試*1 } \\
\text { Chlorella } \\
\text { vulgaris }\end{array}$} & \multirow{2}{*}{\begin{tabular}{|c|} 
広島水試*2 \\
$\begin{array}{c}\text { Chlorella } \\
\text { sp. }\end{array}$
\end{tabular}} & \multirow{2}{*}{ 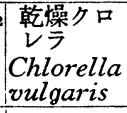 } & \\
\hline & 1975 & 1977 & & & 9 月 1977 & 5 月 1976 & & & & \\
\hline $14: 0$ & 0.3 & 2.2 & 1.1 & 3.1 & 4.8 & 4.3 & 4.8 & 5.2 & 0.5 & 5.6 \\
\hline $16: 0$ & 8.3 & 16.8 & 11.2 & 20.0 & 26.1 & 22.5 & 20.2 & 19.7 & 23.4 & 11.1 \\
\hline $16: 1 \omega 7$ & 38.2 & 32.8 & 14.2 & 27.2 & 26.3 & 22.3 & 29.5 & 30.5 & 6.6 & 25.2 \\
\hline $18: 0$ & 4.1 & 3.4 & 8.4 & 4.7 & 1.1 & 1.0 & Tr. & 0.7 & 5.7 & 0.1 \\
\hline $18: 1 \omega 9$ & 43.9 & 28.5 & 38.0 & 26.1 & 6.2 & 3.1 & 8.6 & 2.7 & 21.2 & 3.5 \\
\hline $18: 2 \omega 6$ & 2.8 & 7.6 & 15.1 & 10.9 & 2.3 & 3.4 & 4.1 & 2.4 & 21.9 & 2.5 \\
\hline $18: 3 \omega 3$ & 0.5 & 1.8 & 6.4 & 3.2 & 0.2 & 0.1 & Tr. & 0.2 & 4.6 & 0.1 \\
\hline $20: 1$ & 0.2 & Tr. & 1.6 & 0.8 & 0.1 & 0.1 & - & & 0.3 & Tr. \\
\hline $20: 3 \omega 3$ & & & & & 39 & 47 & 24 & 36 & 0.1 & 4.9 \\
\hline $20: 4 \omega 6\}$ & & & & & 3.9 & & 2.4 & 3.0 & 0.1 & 4.9 \\
\hline $20: 4 \omega 3$ & & & & & - & 0.1 & & & 0.1 & Tr. \\
\hline $20: 5 \omega 3$ & & & & & 24.8 & 31.8 & 26.6 & 27.8 & - & 37.8 \\
\hline $22: 5 \omega 3$ & & & & & & & & 1.7 & 0.3 & - \\
\hline $22: 6 \omega 3$ & & & & & & & & 0.8 & - & - \\
\hline
\end{tabular}

*1 協和醗酵 (株) 今田 克氏提供

*2 広島県水産試験場, 昭和 51 年度指定調査研究総合助成事業報告

パン酵母の脂肪酸組成をみると, 各社のパン酵母に同 ビ傾向がみられ，いずれも $16: 1 \omega 7,18: 1 \omega 9$ の割合 が高く, 両モノェン酸だけで 52 82\% にも達し， $\omega 3$ HUFA を含有しない(表-3)。このような組成のパン 酵母で培荃したわむしでモノエン酸含量が高く, $\omega 3$ HUFA 含量が低いのは当然といえよう。

一方, 長崎水試の海産クロレラでは，モノエン酸含量 が低く, $\omega 3$ HUFA の割合が高い。1976 年と 1977 年の クロレラでは培垗の時期と条件が異なるためか, 多少差 はあるが、いずれも20:5 53 の割合が高く，25〜32\% に達している。山口県内海栽培漁業センター及び広島県 水産試験場のクロレラも, 種類は異なるが, 長崎水試の クロレラとほぼ同し組成をもち, $20: 5 \omega 3$ の含量の高 いのが特徴となっている。また熊本県水産試験場でク口 レラわむしの培荃に使用しているものは, クロレラでは なく, Nannochloris coccoides であるが, やはりクロレ ラと同じうな組成をもっている。すなわち, 海産ク口 レラで培荃すると, わむしがクロレラ中の $20: 5 \omega 3$ を 直接取り込む結果, クロレラわむしで $20: 5 \omega 3$ 含量が 高いわけである。しかし, 同じ Chlorella vulgaris で も，人工海水を用いて培養したものでは，20:5 03 を 含まず, $18: 2 \omega 6$ の割合が著しく高く, 後述する淡水 クロレラの脂肪酸組成に似ている。同一種のクロレラで も培秋条件などによってその組成が異なるものと推察さ れる。

乾燥粉末の淡水クロレラ及び岐阜水試で醂母わしし 二次培荃に使用した生の淡水クロレラの脂肪酸組成の一 部を表-4にあげた。Chlorella regularis では乾燥粉末 で $16: 4 \omega 3$ の割合が高く, $18: 2 \omega 6$ の含量が低いが,
表-4 淡水産の乾燥及び生クロレラの総脂質脂肪酸組成

\begin{tabular}{|c|c|c|c|c|c|}
\hline \multirow{3}{*}{ 脂 眆 酸 } & \multirow{3}{*}{$\begin{array}{c}\text { 生 } \\
\begin{array}{c}\text { Chlorella } \\
\text { regularis }\end{array} \\
1976\end{array}$} & \multicolumn{3}{|c|}{ 乾 } & 喿 \\
\hline & & \multicolumn{3}{|c|}{ Chlorella regularis } & $\begin{array}{c}\text { Chlorella } \\
\text { sp. }\end{array}$ \\
\hline & & 1975 & 1976 & 1977 & 1976 \\
\hline $14: 0$ & 0.5 & 1.0 & 0.7 & 0.3 & 1.2 \\
\hline $16: 0$ & 16.9 & 11.1 & 6.3 & 23.5 & 13.0 \\
\hline $16: 1 \omega 7$ & 2.7 & 1.7 & 3.5 & 2.0 & 23.5 \\
\hline $\left.\begin{array}{l}16: 2 \\
17: 0\end{array}\right\}$ & 18.0 & 15.4 & 26.3 & 12.3 & 3.7 \\
\hline $16: 4 \omega 3$ & 6.8 & 37.7 & 37.3 & 7.0 & 2.3 \\
\hline $18: 0$ & 4.1 & 0.5 & 0.8 & 5.6 & 8.8 \\
\hline $18: 1 \omega 9$ & 3.5 & 1.6 & 0.7 & 3.5 & 6.1 \\
\hline $18: 2 \omega 6$ & 37.3 & 11.1 & 8.3 & 32.9 & 9.7 \\
\hline $18: 3 \omega 3\}$ & 9.1 & 14.4 & 12.0 & 9.8 & 13.5 \\
\hline $\begin{array}{l}18: 4 \omega 3 \\
20: 0\end{array}$ & 0.1 & - & - & 0.3 & 2.6 \\
\hline $20: 1$ & 0.1 & Tr. & 0.4 & 0.1 & - \\
\hline $\left.\begin{array}{l}20: 3 \omega 3 \\
20: 4 \omega 6\end{array}\right\}$ & Tr. & - & 0.6 & Tr. & 0.1 \\
\hline $20: 5 \omega 3$ & 0.2 & Tr. & 0.3 & 0.2 & 1.0 \\
\hline $22: 1$ & - & Tr. & 0.4 & 0.6 & - \\
\hline
\end{tabular}

いずれの淡水クロレラも海産クロレラと大きく異なり, $\omega 3$ HUFA の含量が著しく低く, $18: 3 \omega 3$ の含量が高 い。このような組成をもつ淡水クロレラで培養した結 果, 岐阜水試のクロレラわむしで $18: 2 \omega 6$ 及び 18 : $3 \omega 3$ の含量が高く, $\omega 3$ HUFA の割合が低くなったも のと考えられる。

淡水クロレラには $16: 4 \omega 3$ や $18: 3 \omega 3$ などの $\omega 3$ 脂肪酸が比較的高濼度に含まれているが，培趇されたわ むしには $\omega 3$ HUFA がほとんど存在しないことから， 
渡辺らはわむし体内では $16: 4 \omega 3$ や $18: 3 \omega 3$ は 20 : $5 \omega 3$ や $22: 6 \omega 3$ などの $\omega 3$ HUFA へはほとんど転換 されないものと推察している。18: $3 \omega 3$ はにじますな どの EFA であるが，まだいに対しては EFA の効果を もたず,むしろ過剩の $18: 3 \omega 3$ は肝蔵に脂肪の蓄積を

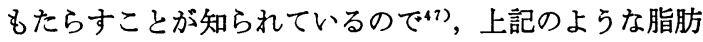
酸組成をもつわむしは, 淡水魚の場合は別として, 海産 魚に対しては栄養価が低いものと考えられる。そのた め, 淡水クロレラや乾燥粉末のクロレラを使用する場合 には，その組成を充分に吟味する必要があろう。

\section{3 アルテミア Artemia salina}

わむしでし魚後期末まで飼育した変態期前後の稚魚と 魚介肉ミンチにえ付けさせる時期に甲殻類プランクトン はたいへん優れたし料であるが，現状では入手が不安定 なため，アルテミア幼生が補助的に使用されている。し かし、アルテミア幼生を単独に連続給じすると,大量へい 死を招くことが数種の魚種で知られている。天然プラン クトンや魚介肉ミンチを併用すると, この現象が緩和さ

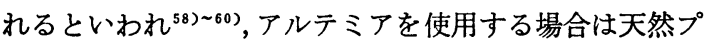
ランクトン, わむし, 魚介肉ミンチなどと混合給じをし, その間に魚介肉ミンチへのえさの切り替えが行われる。

最近, アルテミアの栄養価を EFA からみた場合, そ の脂肪酸組成に問題があることが指摘されている ${ }^{6)}$ 。

渡辺ら ${ }^{6)}$ が分析した 1975 年のサンフランシスコ産ア ルテミアの脂肪酸組成の一部を 表-5 に示した。各機関 でふ化条件やふ化後経過日数などに多少の相違がある が，いずれのアルテミアもよく似た脂肪酸組成を示して
いる。総脂質の脂肪酸組成をみると, $18: 1 \omega 9$ 及び 18: $: 3 \omega 3$ が主成分となっており, $\mathrm{C}_{20}$ 以上の高度不飽 和 酸の含量が低い。18:3 $\omega 3$ の含量が 約 $28 \%$ と高く, 海産の動物し料としては大変珍しい脂肪酸組成といえよ う。Wickins ${ }^{61)}$ もュタ産及びサンフランシスコ産アルテ ミア幼生で同じような組成をみている。
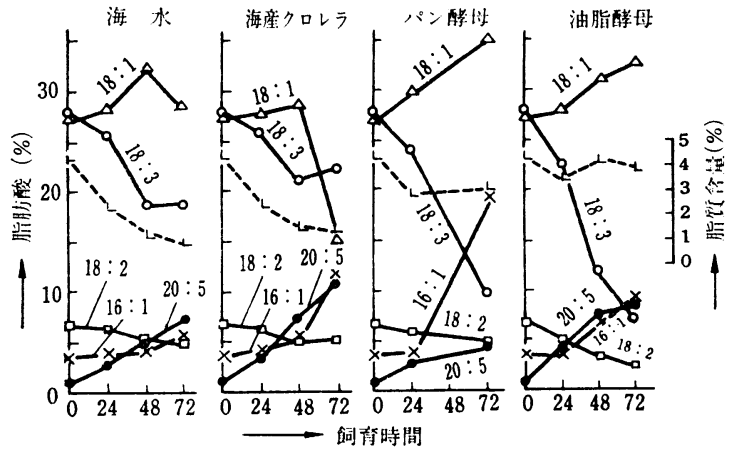

図-3 1976年サンフランシスコ産フルテミア幼生の脂肪 酸組成に及ぼすし料の影響

アルテミアの脂翼に多量に存在する $18: 3 \omega 3$ は, 淡 水魚あるいはくるまえ(゙62) 64) などの EFA なので, 淡 水魚に対しては有効な生物し料といえよう。しかし，ま だいなどの海水魚の EFA である $20: 5 \omega 3$ や $22: 6 \omega 3$ などの $\omega 3$ HUFA の含量が非常に低い。さらに前述し たように, $18: 3 \omega 3$ はまだいにとって EFA としての 効果はなく，むしろ悪影響を及ぼすので，この年のサン フランシスコ産アルテミアの海産魚に対する栄養価は低 いものと推察される。

表-5 各機関でぶ化させた 1975 年度サンフランシスコ産アルテミア卵及び幼生の各脂質画分の脂肪酸組成

\begin{tabular}{|c|c|c|c|c|c|c|c|c|c|c|c|c|}
\hline \multirow{3}{*}{ 脂 肪 酸 } & \multicolumn{2}{|r|}{ 総 } & \multicolumn{2}{|l|}{ 詣 質 } & \multicolumn{2}{|c|}{ 極 } & \multicolumn{2}{|c|}{ 質 } & \multicolumn{4}{|c|}{ トリ } \\
\hline & 卵 & 红 & 生 & & 卵 & \& & 生 & & 卵 & & 生 & \\
\hline & 東水大 & | 長崎水試 & 岐阜水試 & 東水大 & 東水大 & 長崎水試 & 岐阜水試 & 東水大 & 東水大 & 長崎水註 & 岐阜水試 & 東水大 \\
\hline $14: 0$ & 1.1 & 0.9 & 0.8 & 1.1 & 1.2 & 0.5 & 0.4 & 0.3 & 1.2 & 1.1 & 1.5 & 1.3 \\
\hline $16: 0$ & 13.2 & 11.4 & 10.7 & 11.2 & 16.3 & 9.6 & 10.0 & 10.3 & 14.1 & $13.6^{\circ}$ & 14.2 & 13.5 \\
\hline $16: 1 \omega 7$ & 4.5 & 3.2 & 4.1 & 4.3 & 3.2 & 1.7 & 2.7 & 2.5 & 4.1 & 4.0 & 4.8 & 4.7 \\
\hline $\left.\begin{array}{l}16: 2 \\
17: 0\end{array}\right\}$ & 1.4 & 2.0 & 2.0 & 1.5 & 0.8 & 1.6 & 1.8 & 1.4 & 1.8 & 2.3 & 2.2 & 2.2 \\
\hline $18: 0$ & 4.0 & 6.0 & 5.0 & 4.4 & 6.6 & 10.8 & 11.3 & 8.2 & 3.7 & 4.4 & 3.4 & 3.6 \\
\hline $18: 1 \omega 9$ & 27.8 & 28.7 & 28.7 & 25.1 & 33.1 & 36.7 & 39.0 & 36.8 & 26.6 & 29.1 & 28.8 & 25.5 \\
\hline $18: 2 \omega 6$ & 6.2 & 6.6 & 6.6 & 6.1 & 6.1 & 6.1 & 6.8 & 5.4 & 6.6 & 6.2 & 6.7 & 6.3 \\
\hline $18: 3 \lll 3$ & 27.7 & 27.6 & 28.1 & 28.4 & 16.6 & 19.2 & 14.3 & 19.1 & 29.9 & 26.6 & 23.9 & 29.4 \\
\hline $\left.\begin{array}{l}18: 4 \omega 3 \\
20: 0\end{array}\right\}$ & 3.6 & 3.1 & 3.5 & 4.5 & 4.8 & 2.5 & 1.9 & 3.3 & 3.3 & 1.5 & 1.9 & 2.2 \\
\hline $\left.\begin{array}{l}20: 3 \omega 3 \\
20: 4 \omega 6\end{array}\right\}$ & 0.6 & 1.2 & 1.0 & 1.0 & 2.3 & 2.1 & 1.7 & 2.1 & 0.4 & 0.8 & 0.8 & 0.7 \\
\hline $20: 4 \omega 3$ & 0.3 & 0.3 & 0.3 & 0.3 & 0.2 & 0.4 & 0.3 & 1.3 & 0.4 & 0.3 & 0.2 & 0.3 \\
\hline $20: 5 \omega 3$ & 1.8 & 2.3 & 2.1 & 3.1 & 3.1 & 4.2 & 3.3 & 5.0 & 1.4 & 1.1 & 1.4 & 1.2 \\
\hline$\Sigma \omega 6$ & 7.4 & 8.2 & 7.9 & 7.7 & 9.4 & 8.7 & 9.4 & 8.3 & 7.3 & 7.5 & 8.1 & 7.2 \\
\hline$\Sigma \omega 3$ & 35.2 & 34.7 & 35.5 & 38.0 & 25.8 & 27.2 & 20.9 & 29.4 & 36.5 & 31.3 & 28.7 & 34.3 \\
\hline
\end{tabular}


このような脂肪酸組成をもつアルテミアを，各種し料 て飼育すると, 脂質含量及び $18: 3 \omega 3$ の割合が減少 し, $20: 5 \omega 3$ の含量の増加がみられる ${ }^{6}$ (図-3)。ふ化 後の経過時間が長くなると，脂質含量が激減することは 藤田ら ${ }^{65)}$ も認めている。また Morris $ら^{66)}$ は，子化直後 のアルテミアはし魚のし料として好適であるが，卵黄を 吸収しつくしたものは劣ると報告している。恐らく脂質 含量の低下と水分含量の増加による総エネルギー含量の 減少によるものと思われるが，子化後経過時間が長くな るにつれて $18: 3 \omega 3$ が減少し, $20: 5 \omega 3$ が増加する ので，海産魚に対する栄養価はむしろ改善されるものと 考えられる。

また， $\omega 3$ HUFA を多量に含む海産クロレラや後述 する油脂酵母などで飼育すると, アルテミアの $20: 5 \omega$ 3 の割合が増加するので, し料効果も改善されると推察 される。渡辺ら ${ }^{10}$ は, $18: 3 \omega 3$ 含量の高いアルテミア を海産クロレラあるいは油脂酵母で飼育し，まだい稚魚 に対するし料効果を調べた結果, 海産クロレラや油脂酵 母から $\omega 3$ HUFA を取り込むことによって, し料効果 が著しく改善されたと報告している(表-6)。Wickins ${ }^{61}$ )

表-6 海産クロレラ及び油脂酵母で飼䏍したアル テミテのし料効果

\begin{tabular}{|c|c|c|c|c|}
\hline & $T$ & ル & テ & T \\
\hline & カナダ産 & \multicolumn{3}{|c|}{ サンフランシスコ産 } \\
\hline & $\begin{array}{l}\text { 六化直後 } \\
\text { 幼 生 }\end{array}$ & $\begin{array}{l}\text { 岕化值後 } \\
\text { 幼 生 }\end{array}$ & $\begin{array}{l}\text { 海産クロレ゙ } \\
\text { 夸で24h 飼 } \\
\text { 育した幼生 }\end{array}$ & $\begin{array}{l}\text { 油脂酵母で } \\
24 \mathrm{~h} \text { 飼育し } \\
\text { た幼生 }\end{array}$ \\
\hline $\begin{array}{l}\text { 供試尾数 } \\
\text { 全 長 }(\mathrm{mm})\end{array}$ & 500 & 500 & 500 & 500 \\
\hline 開始時 & $6.91 \pm 0.63$ & $6.91 \pm 0.63$ & $6.91 \pm 0.63$ & $6.91 \pm 0.63$ \\
\hline 終了時 & $9.57 \pm 1.35$ & $10.13 \pm 1.34$ & $11.13 \pm 1.73$ & $11.67 \pm 2.03$ \\
\hline 生 残 率(96) & 68.0 & 49.2 & 66.0 & 86.4 \\
\hline 活力テスト (\%) & 37.5 & 24.1 & 46.1 & 50.0 \\
\hline
\end{tabular}

も，Isochrysis galbana をアルテミア幼生に給じするこ とによって，すじえび類に対するユタ産アルテミア幼生 のし料欠陥を補ったという。渡辺ら ${ }^{67)}$ の分析結果では, I. galbana は $20: 5 \omega 3$ 及び $22: 6 \omega 3$ の含量が高い。 これら $\omega 3$ HUFA を取り込んだ結果とも考えられる。 このことはまた, $\omega 3$ HUFA 含量の高いTigriopus や Acartia などと併用すると同じ効果がみられることから もうかがわれる60)。

つぎに, 1977 年度のサンフランシスコ, 南アメリカ, 及びカナダ産アルテミアの脂肪酸組成の一部を 表-7 に 示す。卵の脂質含量は産地によりかなり差があるが, 幼 生では大差ないようである。またいずれの産地のアルテ ミアも, 卵と幼生は互いによく似た脂肪酸組成をもって いる。南アメリカのアルテミアは従来のサンフランシス 二産のものに比較的近い組成をもっており, $18: 3 \omega 3$ の含量が高く, $\omega 3$ HUFA 含量が低い。しかし，サンフ
表-7 1977年度サンフランシスコ産, カナダ産及び南了 メリカ産アルミテフの卵及び幼生の脂肪酸組成

\begin{tabular}{|c|c|c|c|c|c|c|}
\hline \multirow{2}{*}{ 脂 肪 酸 } & \multicolumn{3}{|c|}{ 卵 } & \multicolumn{3}{|c|}{ S化直後幼生 } \\
\hline & $\begin{array}{l}\text { サソフラ } \\
\text { ソシスコ }\end{array}$ & $\begin{array}{l}\text { 南了メ } \\
\text { リカ }\end{array}$ & カナダ & $\begin{array}{l}\text { サンフラ } \\
\text { ソシスコ }\end{array}$ & $\begin{array}{l}\text { 南了メ } \\
\text { リカ }\end{array}$ & カナダ \\
\hline $14: 0$ & 1.4 & 0.6 & 0.9 & 0.9 & 0.5 & 0.6 \\
\hline $16: 0$ & 12.0 & 10.6 & 10.2 & 9.5 & 7.9 & 8.4 \\
\hline $16: 1 \omega 7$ & 18.4 & 6.4 & 9.9 & 12.0 & 5.8 & 7.3 \\
\hline $\left.\begin{array}{l}16: 2 \\
17: 0\end{array}\right\}$ & 1.0 & 1.7 & 1.5 & 0.9 & 1.9 & 2.2 \\
\hline $18: 0$ & 3.6 & 5.5 & 3.7 & 6.8 & 5.9 & 7.0 \\
\hline $18: 1 \omega 9$ & 31.5 & 25.0 & 27.8 & 36.1 & 26.3 & 30.0 \\
\hline $18: 2 \omega 6$ & 4.0 & 5.6 & 7.2 & 3.4 & 5.2 & 6.0 \\
\hline $18: 3 \omega 3$ & 9.0 & 18.6 & 13.7 & 10.3 & 21.0 & 13.5 \\
\hline $\left.\begin{array}{l}18: 4 \omega 3 \\
20: 0\end{array}\right\}$ & 1.7 & 4.2 & 1.4 & 1.2 & 6.5 & 0.6 \\
\hline $\left.\begin{array}{l}20: 3 \omega 3 \\
20: 4 \omega 6\end{array}\right\}$ & 1.6 & 0.3 & 2.4 & 2.7 & 0.6 & 3.2 \\
\hline $20: 4 \omega 3$ & 0.9 & 0.5 & 0.3 & 0.4 & 0.7 & 0.2 \\
\hline $20: 5 \omega 3$ & 7.1 & 0.2 & 10.3 & 9.5 & 0.3 & 12.1 \\
\hline $\begin{array}{c}\text { 脂質含量 } \\
\text { \% }\end{array}$ & 6.4 & 10.5 & 4.8 & 2.0 & 1.6 & 2.1 \\
\hline
\end{tabular}

ランシスコ産とカナダ産のアルテミアはこれらのものと 大きく異なり, $18: 3 \omega 3$ 含量が従来のものの半量以下 で, 逆に 20:5 $\omega 3$ の含量が高い。この年の両アルテミ アの海産魚に対する栄養価は従来のものよりは高いと考 えられる。

このように，アルテミアの脂肪酸組成は産地によって 異なり，また同一産地のものでも年度によって大きく異 なることが明らかにされた。アルテミアの捕食する生物 乙料相が年度や産地によって異なるためと考えられ，大

表-8 中国天津産（1979～1981年）アルテミア卵の 総脂質脂肪酸組成

\begin{tabular}{|c|c|c|c|c|c|c|c|c|c|}
\hline \multirow{2}{*}{ 脂肪酸 } & \multicolumn{5}{|c|}{1979} & \multicolumn{3}{|c|}{1980} & \multirow{2}{*}{$\begin{array}{c}1981 \\
\text { A }\end{array}$} \\
\hline & $\mathrm{A}^{* 1}$ & $\mathrm{~B}^{* 1}$ & A & B & $\mathrm{C}$ & A & B & $\mathrm{C}$ & \\
\hline$: 0$ & .9 & 0.8 & 3.0 & 2.8 & 2.0 & 5.0 & 5.5 & 2.1 & 2.0 \\
\hline $16: 0$ & 9.7 & 9.3 & 12.1 & 12.7 & 12.7 & 23.0 & 21.2 & 12.5 & 13.1 \\
\hline $16: 1 \omega 7^{* 2}$ & 13.6 & 13.4 & 22.6 & 24.0 & 22.4 & 24.7 & 22.8 & 20.1 & 19.1 \\
\hline $18: 0$ & 6.0 & 6.0 & 3.5 & 2.9 & 3.3 & 4.4 & 3.8 & 3.2 & 3.3 \\
\hline $18: 1 \omega 9^{* 2}$ & 33.5 & 33.8 & 26.2 & 20.2 & 28.3 & 22.1 & 17.4 & 24.9 & 25.3 \\
\hline $18: 2 \omega$ & 4.4 & 4.4 & 4.1 & 3.8 & 4.3 & 1.6 & 2.2 & 4.2 & 5.0 \\
\hline $18: 3 \omega 3$ & 5.3 & 5.1 & 5.5 & 6.0 & 5.1 & 0.4 & 0.6 & 6.4 & 6.6 \\
\hline $18: 4$ & 0.6 & 0.6 & 0.9 & 1.0 & 0.7 & 0.4 & 0.9 & 1.0 & 1.3 \\
\hline $20: 1$ & 0.7 & 0.7 & 0.2 & 0.4 & - & 1.7 & 1.9 & 0.4 & 0.4 \\
\hline $20: 4 \omega 6$ & 2.8 & 3.0 & 1.2 & 1.1 & 1.5 & 0.8 & 0.7 & 1.8 & 1.4 \\
\hline $20: 4$ & 0.7 & 0.7 & -1 & - & - & - & - & 0.2 & 0.1 \\
\hline $20: 5 \omega 3$ & 13.0 & 13.2 & 9.2 & 10.2 & 11.3 & 1.9 & 1.3 & 10.9 & 9.3 \\
\hline $22: 1$ & - & - & - & - & - & 0.6 & 0.6 & Tr. & 0.7 \\
\hline $22: 6 \omega 3$ & - & - & - & - & - & 0.2 & 0.3 & Tr. & - \\
\hline$\Sigma \omega 3$ & 13.7 & 13.9 & 9.2 & 10.2 & 11.3 & 2.1 & 2.2 & 11.1 & 9.4 \\
\hline Lipid $\not 6$ & 4.2 & 4.4 & 3.7 & 3.9 & 5.2 & - & - & 9.3 & 2.5 \\
\hline
\end{tabular}

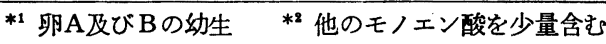


表-91980年度ブラジル及びオーストラリア産丁ルテミア 卵の総脂質脂肪酸組成

\begin{tabular}{|c|c|c|c|c|c|c|c|c|}
\hline \multirow{2}{*}{ 脂 肪 酸 } & \multicolumn{7}{|c|}{ Brazil 1980} & \multirow{2}{*}{$\begin{array}{c}\text { Aus- } \\
\text { tralia } \\
1980\end{array}$} \\
\hline & A & B & $\mathrm{C}$ & $\mathrm{D}$ & $\mathrm{E}$ & $E^{* 1}$ & $\mathrm{~F}$ & \\
\hline $14: 0$ & 3.3 & 3.4 & 2.1 & 3.6 & 2.4 & 1.7 & 2.0 & 1.6 \\
\hline $16: 0$ & 16.0 & 18.2 & 13.7 & 18.0 & 14.7 & 12.2 & 13.7 & 13.9 \\
\hline $16: 1 \omega 7^{* 2}$ & 18.6 & 14.4 & 13.8 & 14.6 & 14.7 & 12.8 & 14.1 & 9.9 \\
\hline $18: 0$ & 1.9 & 2.9 & 3.2 & 2.8 & 2.7 & 4.1 & 2.6 & 2.8 \\
\hline $18: 1 \omega 9^{* 2}$ & 21.8 & 23.7 & 28.9 & 16.2 & 26.6 & 30.7 & 28.3 & 33.3 \\
\hline $18: 2 \omega 6$ & 7.2 & 6.4 & 8.5 & 3.1 & 7.7 & 9.3 & 11.8 & 5.2 \\
\hline $18: 3 \omega 6$ & 1.9 & 3.2 & 0.8 & 5.1 & - & - & - & 0.1 \\
\hline $18: 3 \omega 3$ & 3.3 & 1.1 & 3.2 & 0.9 & 3.6 & 3.3 & 2.7 & 10.1 \\
\hline $18: 4 \omega$ & 0.3 & Tr. & 0.6 & Tr. & 0.7 & 0.4 & 0.9 & 3.8 \\
\hline $20: 1$ & 0.9 & 1.2 & 0.4 & 1.9 & 0.5 & 0.5 & 0.3 & 0.4 \\
\hline $20: 2 \omega 6$ & 0.5 & 0.3 & 0.1 & 0.2 & 0.1 & - & - & 0.2 \\
\hline $20: 4 \omega 6$ & 2.7 & 3.2 & 4.5 & 3.2 & 4.0 & 4.6 & 3.6 & 1.1 \\
\hline $20: 4 \omega 3$ & 0.1 & Tr. & 0.4 & Tr. & 0.3 & 0.4 & 0.2 & 1.0 \\
\hline $20: 5 \omega 3$ & 3.9 & 3.5 & 5.9 & 4.6 & 5.8 & 6.5 & 5.8 & 8.6 \\
\hline $22: 1$ & 0.7 & 1.0 & 0.4 & 1.8 & 0.5 & - & - & Tr. \\
\hline $22: 4 \omega 6$ & 0.4 & 0.5 & 0.1 & 0.9 & - & - & - & $\operatorname{Tr}$. \\
\hline $22: 6 \omega 3$ & 0.4 & 0.6 & Tr. & 1.6 & 0.1 & -1 & 0.2 & 0.2 \\
\hline $\begin{array}{l}\sum \omega 3 \\
\text { HUFA }^{* 8}\end{array}$ & 4.4 & 4.1 & 6.3 & 6.2 & 7.2 & 6.9 & 6.2 & 9.8 \\
\hline Lipid 96 & - & - & 5.4 & -1 & -1 & -1 & - & 7.9 \\
\hline
\end{tabular}

変興味深い。

渡辺ら ${ }^{68)}$ は，1978〜1981 年のサンフランシスコ, カ
ナダ，ブラジル，天津及びオーストラリア産のアルテミ アについても調べており，1977 年と同じ傾向がみられ， 産地などによってかなり異なっていたと報告している (表-8,9 及び 10)。

さらに, $20: 5 \omega 3$ 含量の高い海産魚タイプのアルテ ミアでは単用しても大量へい死を起こさないとしてい る。18: $3 \omega 3$ 含量の高い淡水魚タイプのアルテミアに $\omega 3$ HUFA を取り込ませることによって海産魚に対する し料効果を改善できることを併せ考えると, アルテミア 単用によるし稚魚の大量へい死などの原因の一つは, そ の脂肪酸組成によるものと推察される。このことからア ルテミアの含有する EFA の内容が不明な場合には，で きるだけ単用は避け，他の生物し料と併用することが好 ましいと考えられる。

\section{4 チグリオパス Tigriopus japonica}

チグリオパスは $7 \mathrm{~mm}$ 以降のし稚魚のし料として各地 の種苗生産の現場で使用されており，し料効果も優れて いる。最近, 長崎水試ではパン酵母，しょう油かすある いは鶏ふんによる量産方法を検討し，パン酵母給じによ るチグリオパスとわむしの混合生産が最も効果的である ことを明らかにした ${ }^{69)}$ 。この方法によると, 種苗生産期 間中に $80 \sim 100 \mathrm{~kg}$ のチグリオパスを計画的に生産でき るという。

各種し料を用いて培養したチグリオパスの脂質含量, 及び総脂質の脂肪酸組成の一部を表-11に示した ${ }^{70)}$ 。

表-10 サンフランシスコ産 (1979 1981 年) アルテミア卵及び幼生の総脂質脂肪酸組成

\begin{tabular}{|c|c|c|c|c|c|c|c|c|c|c|c|c|}
\hline \multirow{2}{*}{ 脂 肪 酸 } & \multirow{2}{*}{$\begin{array}{c}1979 \\
\text { A }\end{array}$} & \multicolumn{8}{|c|}{1980} & \multicolumn{3}{|c|}{1981} \\
\hline & & A & B & $\mathrm{C}$ & D & $\mathrm{E}$ & $\mathrm{F}^{* 1}$ & $\mathrm{G}^{* 1}$ & $\mathrm{H}^{* 1}$ & A & B & C \\
\hline $14: 0$ & 2.3 & 3.5 & 2.9 & 3.6 & 1.3 & 2.1 & 2.2 & 0.6 & 0.7 & 1.6 & 1.1 & 0.7 \\
\hline $16: 0$ & 13.3 & 26.6 & 25.3 & 25.9 & 14.9 & 23.7 & 9.2 & 11.0 & 12.2 & 15.2 & 13.6 & 10.6 \\
\hline $16: 1 \omega 7^{* 2}$ & 16.4 & 16.3 & 15.7 & 12.9 & 5.5 & 7.4 & 14.8 & 3.8 & 10.4 & 10.5 & 4.3 & 5.4 \\
\hline $18: 0$ & 2.4 & 5.1 & 5.1 & 3.7 & 3.5 & 4.1 & 2.0 & 3.3 & 3.2 & 2.9 & 3.2 & 3.0 \\
\hline $18: 1 \omega 9^{* 2}$ & 28.2 & 25.8 & 27.6 & 19.8 & 28.0 & 23.7 & 19.1 & 26.7 & 34.9 & 28.5 & 27.1 & 26.3 \\
\hline $18: 2 \omega 6$ & 8.3 & 2.6 & 2.9 & 2.5 & 6.3 & 5.4 & 8.3 & 8.9 & 6.6 & 7.1 & 6.1 & 7.6 \\
\hline $18: 3 \omega 6$ & 0.9 & 0.5 & 0.4 & 0.6 & - & - & 1.2 & - & 0.4 & 0.6 & - & 0.8 \\
\hline $18: 3 \omega 3$ & 2.3 & 3.3 & 4.2 & 4.8 & 22.4 & 14.7 & 5.4 & 27.6 & 17.2 & 17.2 & 28.1 & 27.0 \\
\hline $18: 4 \omega 3$ & 0.2 & 0.3 & 0.9 & 1.1 & 3.2 & 3.4 & 0.6 & 6.0 & 2.5 & 2.7 & 3.6 & 5.2 \\
\hline $20: 1$ & 0.1 & 0.9 & 1.2 & 1.1 & 0.3 & 1.0 & Tr. & 0.5 & 0.5 & 0.4 & 0.4 & 0.5 \\
\hline $20: 2 \omega 6$ & 0.1 & 1.2 & 1.2 & 1.0 & 0.3 & 0.6 & Tr. & 0.1 & 0.1 & - & - & 0.1 \\
\hline $20: 4 \omega 6$ & 7.7 & 2.7 & 0.7 & 0.6 & 0.8 & 0.8 & 3.5 & 1.1 & 1.4 & 1.4 & 0.7 & 1.3 \\
\hline $20: 4 \omega 3$ & - & 0.1 & Tr. & Tr. & 0.2 & 0.5 & 0.3 & 0.9 & 0.3 & 0.4 & - & 0.9 \\
\hline $20: 5 \omega 3$ & 7.5 & 3.9 & 1.7 & 0.9 & 2.7 & 0.6 & 6.8 & 0.3 & 3.5 & 3.6 & 2.4 & 2.1 \\
\hline $22: 1$ & - & 0.7 & 0.5 & 0.3 & 0.6 & 0.3 & Tr. & - & 0.3 & - & 0.2 & Tr. \\
\hline $22: 4 \omega 6$ & - & 0.3 & 0.2 & 0.4 & - & - & 0.2 & 0.1 & - & - & - & 0.2 \\
\hline $22: 6 \omega 3$ & 0.1 & 4.0 & 0.1 & 0.2 & 0.1 & 0.1 & 0.2 & - & Tr. & - & - & - \\
\hline $\begin{array}{l}\Sigma \omega 3 \\
\text { HUFA*3 }\end{array}$ & 7.6 & 4.4 & 1.8 & 1.1 & 3.0 & 1.2 & 7.3 & 1.2 & 3.8 & 4.0 & 2.4 & 3.0 \\
\hline Lipid 96 & 2.9 & - & - & - & - & - & 1.9 & 3.9 & 2.3 & - & - & 3.5 \\
\hline
\end{tabular}

*1 ふ化直後の幼生 ${ }^{* 2}$ 他のモノエン酸を少量含む ${ }^{* 2} \mathrm{C}_{30: 3}<\omega 3$ 脂肪酸 
表-11 各栎し料で培養したチグリオパス Tigriopus japonicus の総脂質脂肪酸組成

\begin{tabular}{|c|c|c|c|c|c|c|c|c|c|c|c|}
\hline \multirow{3}{*}{ 脂 肪 酸 } & \multirow{3}{*}{$\begin{array}{l}\text { 自然条件下 } \\
11 \text { 月 2月 } \\
1975 \sim 1976\end{array}$} & \multicolumn{10}{|c|}{ Tigriopus japonicus } \\
\hline & & \multicolumn{3}{|c|}{ パン 酵 母 } & \multicolumn{3}{|c|}{ パン酵母+クロレラ } & \multirow{2}{*}{ 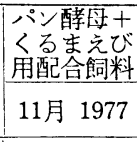 } & \multirow{2}{*}{$\frac{\text { 油脂酵母 }}{11 \text { 月 } 1977}$} & \multicolumn{2}{|c|}{ しょう油かす } \\
\hline & & 12 月 1976 & $\begin{array}{c}11 \text { 月 } \\
\text { I }\end{array}$ & $\begin{array}{c}1977 \\
\text { II }\end{array}$ & $\begin{array}{c}6 \text { 月 } \\
\mathrm{I}\end{array}$ & $\begin{array}{c}1976 \\
\text { II }\end{array}$ & $\begin{array}{l}11 \text { 月 } \\
1977\end{array}$ & & & 12月 1976 & 11月 1977 \\
\hline $1 \div: 0$ & 1.7 & 1.2 & 1.1 & 1.5 & 0.9 & 1.1 & 1.4 & 1.3 & 2.4 & 0.5 & 0.9 \\
\hline $14: 1$ & 0.2 & 4.5 & 5.0 & 6.5 & 3.9 & 3.5 & 6.6 & 5.1 & 2.0 & 2.3 & 2.9 \\
\hline $15: 0$ & 2.1 & 2.0 & 2.2 & 1.6 & 2.0 & 1.9 & 3.0 & 2.2 & 1.5 & 1.3 & 1.9 \\
\hline $16: 0$ & 14.0 & 10.4 & 8.5 & 13.3 & 10.5 & 10.6 & 10.3 & 11.5 & 12.1 & 20.1 & 15.5 \\
\hline $15: 1 \omega 7$ & 6.3 & 10.9 & 14.2 & 11.1 & 11.5 & 10.7 & 10.9 & 8.7 & 8.1 & 5.1 & 4.7 \\
\hline $18: 0$ & 2.3 & 6.0 & 5.0 & 4.6 & 4.5 & 3.8 & 3.1 & 3.1 & 3.6 & 4.3 & 3.6 \\
\hline $18: 1 \omega 9$ & 20.1 & 11.2 & 23.0 & 15.3 & 19.4 & 18.6 & 16.6 & 20.1 & 21.3 & 15.0 & 19.9 \\
\hline $18: 2 \omega 6$ & 2.5 & 3.6 & 2.1 & 2.7 & 3.5 & 3.8 & 3.1 & 5.2 & 1.7 & 7.0 & 18.1 \\
\hline $18: 3 \omega 3$ & 8.2 & 6.0 & 1.8 & 5.5 & 6.1 & 7.8 & 7.4 & 6.1 & 1.3 & 1.8 & 2.7 \\
\hline $\left.\begin{array}{l}18: 4 \omega 3 \\
20: 0\end{array}\right\}$ & 3.2 & 1.9 & 1.2 & 4.3 & 2.0 & 2.2 & 3.7 & 1.4 & 0.8 & 2.0 & 0.3 \\
\hline $20: 1$ & 1.0 & 2.1 & 1.3 & 0.9 & 1.8 & 1.0 & 0.4 & 1.1 & 4.8 & 0.5 & 0.8 \\
\hline $\left.\begin{array}{l}20: 3 \omega 3 \\
20: 4 \omega 6\end{array}\right\}$ & 1.7 & 2.1 & 1.3 & 0.7 & 2.0 & 2.5 & 1.4 & 1.8 & 2.6 & 1.6 & 2.2 \\
\hline $20: 4 \omega 3$ & 2.5 & 2.5 & 1.2 & 1.3 & 2.9 & 3.1 & 1.3 & 2.2 & 1.0 & 1.0 & 1.2 \\
\hline $20: 5 \omega 3$ & 8.2 & 7.2 & 5.7 & 4.2 & 5.8 & 5.9 & 6.8 & 6.8 & 10.8 & 9.3 & 4.4 \\
\hline $22: 5 \omega 3$ & 0.7 & 1.6 & 0.5 & 0.5 & 2.0 & 2.2 & 0.6 & 0.6 & 1.2 & 0.5 & 0.6 \\
\hline $22: 6 \omega 3$ & 6.5 & 12.0 & 10.0 & 8.5 & 9.6 & 9.7 & 6.4 & 7.8 & 13.6 & 16.7 & 7.9 \\
\hline$\Sigma \omega 3$ HUFA & 17.9 & 23.3 & 17.4 & 14.5 & 20.3 & 20.9 & 15.1 & 17.4 & 26.6 & 27.5 & 14.1 \\
\hline 脂質含量 96 & 2.6 & 3.2 & 2.2 & 2.4 & 3.6 & 2.8 & 3.1 & 2.6 & 2.6 & 1.7 & 3.0 \\
\hline
\end{tabular}

脂質含量は $1.7 \sim 3.6 \%$ の範囲にあり，培養年度，季節 あるいはし料によって異なっている。同じ傾向が脂肪酸 組成にもみられるが，いずれのチグリオパスも魚類，特 に海産魚の EFA である $\omega 3$ HUFA の含量が高く, 14 〜27\% に達し，EFA からみて優れた生物し料といえよ う。また $\omega 3$ HUFA を含まないパン酵母やしょう油か すで培養しても $\omega 3$ HUFA 含量が高く, チグリオパスの 脂肪酸組成はわむしほど顕著には培養し料の影響を受け ないようである。これは培養が粗放的であるため，培養 の過程で生じる微小藻類, わむしあるいはデトリタス* などを培養し料とともに捕食していることや，培養時期 によって水温, 天候などの条件が異なる結果, 発生する 生物相が変化するためとも考えられる。そのためチグリ オパスの培養にあたっては, 最高の增殖密度が効率よく 安定して得られる方法を採用すべきであろう。

\section{5 その他の生物し料}

アカルチア Acartia sp. もチグリオパスと同様 $7 \mathrm{~mm}$ 以降のし稚魚に有効なし料として使用されている。しか し, チグリオパスと異なり現状では増殖方法がほとんど 解明されておらず, 天然採集に依存している。採集方法 は夜間の燈火採集か, 潮流利用のネット採集が行われて

*プランクトンやネクトンが生きたまま，あるいは死がいとな って水底にたまったものをいい, 底棲性動物の重要なし料と なっている。
いる。

海産プランクトンの入手が困難な場合には, 淡水産の みじんこもアルテミアと同じょうに補助的に使用され

表-12 たまみじんこ Moina, アカルチフ Acartia 及び けい藻の総脂質脂肪酸組成

\begin{tabular}{|c|c|c|c|c|c|c|c|c|c|}
\hline \multirow{3}{*}{ 脂 眆 酸 } & \multicolumn{5}{|c|}{ Moina sp. } & \multirow{2}{*}{\multicolumn{3}{|c|}{$\frac{\text { Acartia clausi }}{\text { 天然採取 }}$}} & \multirow{3}{*}{$\mid \begin{array}{c}\text { くるま } \\
\text { 光び用 } \\
\text { けい滰 } \\
9 \text { 月 } \\
1977\end{array}$} \\
\hline & \multicolumn{2}{|c|}{ パン酵母 } & \multirow{2}{*}{ 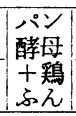 } & \multicolumn{2}{|c|}{ 鴙ふん } & & & & \\
\hline & $\mid$\begin{tabular}{|} 
岐阜 \\
水試
\end{tabular} & $\mid$\begin{tabular}{|c|}
$\mid$ 広島 \\
水試
\end{tabular} & & $5 d$ & $10 \mathrm{~d}$ & \begin{tabular}{|c|}
5 月 \\
1976
\end{tabular} & $\begin{array}{l}\text { 12月 } \\
1976 \\
\end{array}$ & $\left|\begin{array}{c}9 \text { 月 } \\
1977\end{array}\right|$ & \\
\hline$: 0$ & & 2.4 & 0.8 & .3 & 3.2 & .2 & .4 & 2.1 & 23.1 \\
\hline & & & .8 & 10.7 & 9.2 & 16.9 & .0 & 18.3 & .9 \\
\hline & & & 19.9 & 3.8 & 18.1 & .4 & .8 & 10.7 & 14.5 \\
\hline 18: & & 2.5 & 3.0 & 5.6 & 2.3 & 5.4 & 3.8 & 5.0 & 0.2 \\
\hline & .1 & 24.1 & 26.2 & 10.4 & 3.1 & 4.1 & 3.6 & 5.4 & 2.2 \\
\hline : & 4.9 & 4.2 & 6.6 & 7.3 & 2.1 & 1.1 & 0.6 & 1.1 & 1.7 \\
\hline $18:$ & 0.6 & 0.8 & 0.8 & 10.1 & 2.3 & 1.1 & 0.7 & 1.0 & 0.2 \\
\hline$\cdot 0$ & 0.1 & & 1.1 & 2.0 & 2.3 & 3.2 & 2.5 & - & 0.1 \\
\hline$: 1$ & 0 & 0.3 & 0.2 & 0.1 & - & 0.7 & 0.7 & 2.3 & 1. \\
\hline$:$ & 0.3 & 4.4 & 8.9 & 5.5 & 1.7 & 1.1 & 0.4 & 1.0 & 1.7 \\
\hline 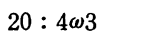 & 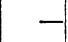 & . 1 & 0.2 & 0.2 & 0.2 & 0.0 & 0.6 & 0.4 & 0.2 \\
\hline 2 & 0.2 & 1.5 & 7.0 & 14.5 & 20.8 & 20.1 & 29.2 & 16.6 & 12.9 \\
\hline & & & 0.2 & 0.2 & 0.5 & 0.5 & 1.0 & 0.8 & - \\
\hline & . & - & 0.3 & Tr. & $\mathrm{Tr}$. & 28.6 & 27.2 & 12.3 & - \\
\hline . & 0.2 & 1.6 & 7.7 & 14.9 & 21.5 & 49.8 & 58.0 & 30.1 & 13.1 \\
\hline 日只只 & & 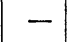 & 1.3 & 1.3 & 3.3 & 1.1 & 1.5 & 1.3 & 1.8 \\
\hline
\end{tabular}


る。これには Daphnia と Moina の類があるが，海水 魚以外にあゆやこいの初期し料としても用いられてい る。

モイナの脂質含量は $1.3 \sim 3.8 \%$ で，培養条件やし料 によって多少異なるが，脂肪酸組成はわむしと同様，培 荃し料に大きく左右される（表-12）。パン酵母で培養し たモイナをみると，いずれもパン酵母の脂肪酸の影響を 受けて, $16: 1,18: 1$ などのモノェン酸含量が非常に 高く， $\omega 3$ HUFA 含量が低、。この組成は酵母わしと たいへんよく似ており，このような組成をもつモイナの 栄養価はいずれの魚種に対しても低いと推察されるので 単用は避けるべきであろう。

一方，パン酵母に鶏ふんを併用すると， $16: 1$ が著し く減少し, $20: 5 \omega 3$ が増加した。さらに鶏ふん単用で 培盖すると，モノエン酸が激減し， $20: 5 \omega 3$ は $5 \mathrm{~d}$ の 培養で $14.5 \%, 10 \mathrm{~d}$ で $20.8 \%$ 一著增する。このモイ ナの組成は，海産クロレラで培養したわむしに似てお り，乙料効果は高いと考えられる。これはチグリオパス の場合と同様, 鶏ふんを水中に散布することにより発生 したさまざまな微小生物を捕食したためと推察される。

長崎県野母湾において採集したアカルチアをみると, 脂肪酸組成には顕著な季節的変動が認められるが，いず れのアカルチアも $20: 5 \omega 3$ 及び $22: 6 \omega 3$ の割合が高 く, 総 $\omega 3$ HUFA が30 58\% に達している。いか肝油 の脂肪酸組成と似ており，海産魚の EFA からみて優れ た生物し料といえよう。アルテミアのし料効果が, チグ リオパスやアカルチアなどと併用すると改善されるの は，この辺に理由があるのかむ知れない。また天然のま だい稚魚で $\omega 3$ HUFA 含量が高い11)のは，アカルチア のような脂肪酸組成をもつプランクトンを捕食している ためと考えられる。

表-13 みじんこ Daphnia の脂肪酸組成

\begin{tabular}{|c|c|c|c|}
\hline 脂 肪 酸 & 総 脂 質 & 極性脂質 & トリグリセリド \\
\hline $12: 0$ & 0.8 & 0.1 & 2.4 \\
\hline $14: 0$ & 2.1 & 1.5 & 3.6 \\
\hline $15: 0$ & 2.2 & 1.2 & 1.8 \\
\hline $16: 0$ & 15.3 & 14.3 & 17.1 \\
\hline $16: 1 \omega 7^{*}$ & 12.4 & 9.6 & 12.2 \\
\hline $18: 0$ & 4.8 & 6.6 & 6.3 \\
\hline $18: 1 \nsim 9^{*}$ & 12.8 & 17.7 & 16.7 \\
\hline $18: 2 \omega 6$ & 4.4 & 4.7 & 3.9 \\
\hline $18: 3 \omega 3$ & 11.0 & 11.0 & 6.4 \\
\hline $\left.\begin{array}{l}18: 4 \omega 3 \\
20: 0\end{array}\right\}$ & 2.9 & 2.0 & 1.8 \\
\hline $\left.\begin{array}{l}20: 3 \omega 3 \\
20: 4 \omega 6\end{array}\right\}$ & 3.6 & 4.0 & 5.2 \\
\hline $20: 4 \omega 3$ & 0.6 & 0.4 & 0.4 \\
\hline $20: 5 \omega 3$ & 16.5 & 16.2 & 7.5 \\
\hline $22: 6 \omega 3$ & 0.2 & 0.7 & - \\
\hline
\end{tabular}

*他のモノェン酸を少量含む
こいの初期し料として培養したみじんこの脂肪酸組成 をみると ${ }^{70)}, \omega 3$ 脂肪酸として $18: 3 \omega 3$ を $11 \%, 20$ : $5 \omega 3$ を $16.5 \%, \omega 6$ 脂肪酸としてて $18: 2 \omega 6$ を $4.4 \%$ 含んでいる（表-13）。このみじんこの培養条件は不明で あるが，脂肪酸組成からみたところでは鶏ふんで培養し たモイナの組成によく似ており, 魚類の初期し料として 適しているようである。

\section{6 酵母わむしのクロレラによる二次培蓦 とし料効果}

酵母わむしのし料効果の改善策として, 給じ前にクロ レラを提らせる処理は，まだい，いしだいなどでなされ， 効果が認められている。このクロレラの処理による効果 は, 20:5 53 の取り込みによると推察した渡辺ら ${ }^{7), 8)}$ は，酵母わむしを海産あるいは淡水クロレラで二次培養 し, $20: 5 \omega 3$ の取り込みの経時的変化とし料効果との 関連について調べている。

\section{1 海産クロレラによる二次培䕉}

酵母わむしにクロレラを $10 \mathrm{~min} \sim 7 \mathrm{~d}$ 経時的に与えた 後, 直ちに回収したものと, $1.5 \mathrm{~h}$ 及び $24 \mathrm{~h}$ 海水中に 放置し, 飢餓の状態にさせたものについて $20: 5 \omega 3$ の 濃度を調べるとともに，乙稚魚に対するし料効果を試験 した。

その結果，図-4 に示したように，いずれの場合も掊
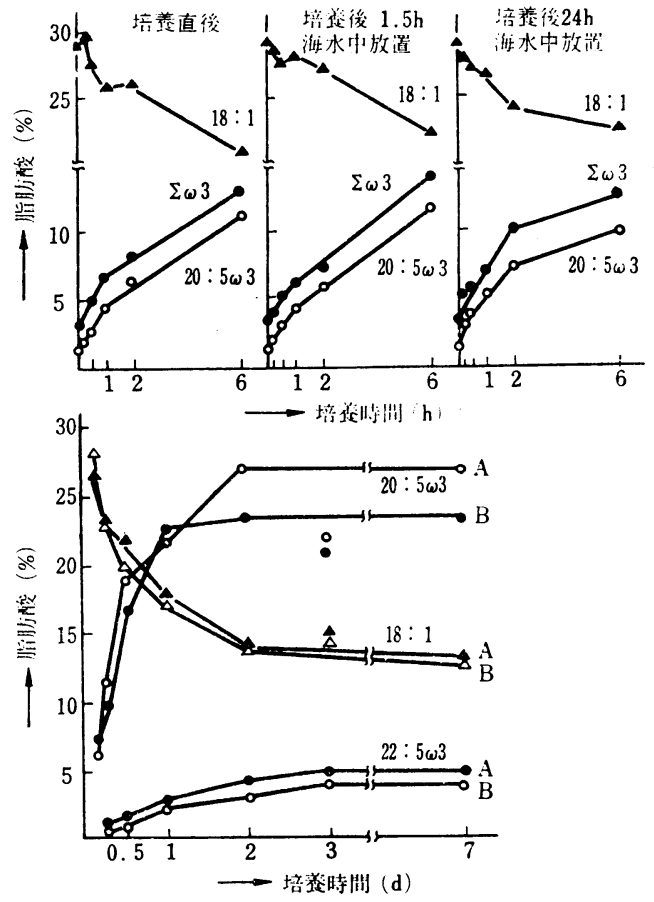

$A$ : 培養直後 $B$ : 培養後 $24 \mathrm{~h}$ 海水中に放置後

図-4 海産クロレラによる二次培養酵母わむしの $20: 5 \omega 3$ 濃度の経時的变化 
養時間に比例して $20: 5 \omega 3$ の濃度が増加し, $6 \mathrm{~h}$ 後で 併用わむしの 10〜12\% レベルに達した。さらに二次培 養を継続すると， $20: 5 \omega 3$ の割合は $6 \mathrm{~h} \rightarrow 24 \mathrm{~h}$ の間で 急激に増加し， $2 \mathrm{~d}$ の培養で $27 \%$ とほぼ最大に達した が，以後培羛を $7 \mathrm{~d}$ 継続してもそれ以上の濃縮は認めら れなかった。この 20:5 $\omega 3$ の取り込みの最大值は今ま でのクロレラわむしで得られている值とよく一致する。 $20: 5 \omega 3$ の濃度に反比例して $18: 1$ の割合が減少し,

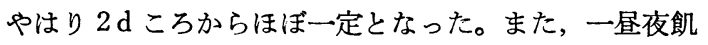
餓の状態にさせると, $20: 5 \omega 3$ の割合は数\% 減少する が, $22: 5 \omega 3$ の割合が逆に増加しているので，わむし 体内で $20: 5 \omega 3$ から $22: 5 \omega 3$ への転換が多少行われ ているものと推察される。

このようにクロレラによる二次培養わむしの $20: 5 \omega$ 3 の割合は, ほぼ $6 \mathrm{~h}$ の培養で併用わむしのレベルに達 し，それにともない酵母わむしのし料効果は表-14にみ られるよらに著しく改善されることがわかった。すなわ ち，酵母わむしとクロレラわむしの栄養価の相違は， $20: 5 \omega 3$ の濃度の相違によるものであり, 酵母わむし

表-14 海産クロレラによる二次培養酵母わむしのし料効果

\begin{tabular}{|c|c|c|c|c|c|}
\hline \multirow{2}{*}{ わむし } & \multirow{2}{*}{ 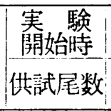 } & \multicolumn{2}{|c|}{ 実験 終了 洔 } & \multirow{2}{*}{$\begin{array}{c}\text { 生残率 } \\
(\%) \\
\text { (\%) }\end{array}$} & \multirow{2}{*}{$\begin{array}{c}\text { 活力テ } \\
\text { ス }{ }^{* 1} \\
(\%)\end{array}$} \\
\hline & & $\begin{array}{l}\text { 聚尾数 } \\
\end{array}$ & 全長 $(\mathrm{mm})$ & & \\
\hline クロレラ & 24,000 & 12,800 & $7.15 \pm 0.52$ & 53.3 & 92.7 \\
\hline $\mathrm{Y} 24 \mathrm{C}^{* 2}$ & $n$ & 14,400 & $6.55 \pm$ & 60.0 & 96.1 \\
\hline $\mathrm{Y} 12 \mathrm{C}$ & $n$ & 9,600 & $6.12 \pm 0.38$ & 49.0 & 87.3 \\
\hline $\mathrm{Y} 6 \mathrm{C}$ & " & 11,900 & $6.31 \pm 0.54$ & 49.6 & 90.7 \\
\hline $\mathrm{Y} 2 \mathrm{C}$ & $"$ & 11,800 & $5.72 \pm 0.53$ & 49.2 & 79.2 \\
\hline 酵母わむし & $" \prime$ & 5,300 & $4.73 \pm 0.30$ & 22.1 & 65.6 \\
\hline $\mathrm{Y} 6 \mathrm{DC} * 3$ & $"$ & 10,700 & $5.13 \pm 0.45$ & 44.6 & 82.4 \\
\hline
\end{tabular}

*1 手網で $5 \mathrm{~s}$ すくった後の生残率

*2 海産クロレラ $24 \mathrm{~h}$ で二次培養した酵母わむし

*8 乾燥淡水産クロレラで $6 \mathrm{~h}$ 二次培養した酵母わむし

によるし稚魚の大量へい死は EFA 欠乏によるものであ ることがほぼ明らかにされた。

長崎水試その他で種苗の量産に使用されている併用わ むしの脂質含量と $20: 5 \omega 3$ の濃度を一つの目安とし て, 二次培養わむしのし料効果と併せ考えると, 酵母わ むしをし稚魚に与える前にクロレラで $6 \mathrm{~h}$ 以上再培養す ることが好ましいと考えられる。

\section{2 淡水クロレラによる二次培蕵}

一方，わむしの培養に淡水クロレラを用いる方法が一 部で試みられており，わむしに対するし料効果が認めら れている72)。淡水産の乾燥クロレラを使用できれば，ク ロレラ培養の手間が省けるとの理由によるものと考えら れる。また海産クロレラの培養が困難なところでは, 酵 母わむしを給じ前に生の淡水クロレラで処理して仕上げ を行っているところもある。

渡辺ら ${ }^{8)}$ は, 乾燥粉末及び生の淡水クロレラを用いて,
海産クロレラの場合と同じ条件で酵母わむしを二次培金 している。淡水クロレラには, 海産クロレラとはかなり 異なり $16: 4 \omega 3,18: 2 \omega 6,18: 3 \omega 3$ が比較的高割合 で含まれており, $\mathrm{C}_{20}$ 以上の高度不飽和酸が少ない。こ のような組成の淡水クロレラで酵母わむしを二次培養し た結果は 図-5 に示すとおりである。海産クロレラを 給じした場合と大きく異なり, 培養時間に比例して, $18: 2 \omega 6$ と $18: 3 \omega 3$ の割合が増加し, $2 \sim 3 \mathrm{~d}$ の培羕
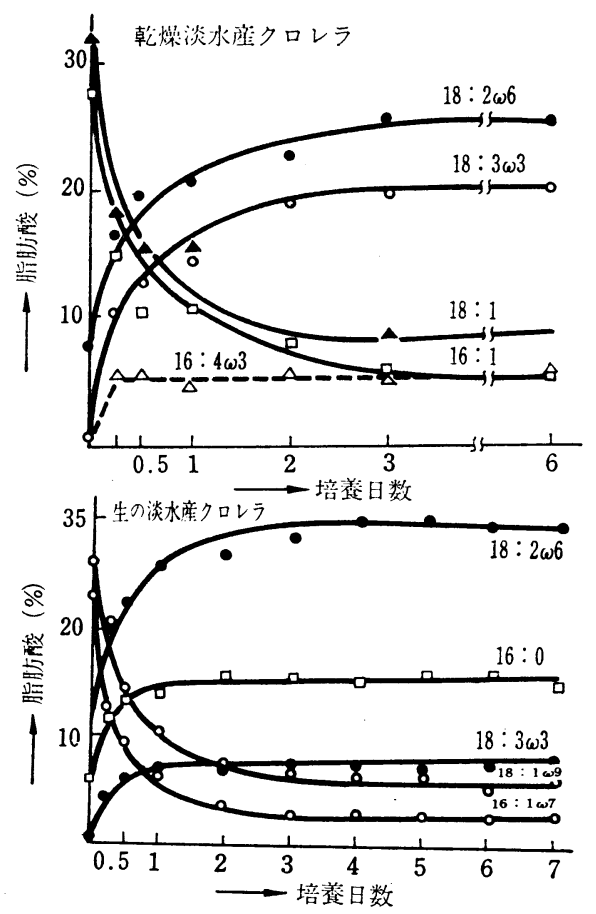

図-5 淡水産クロレラによる二次培養酵母わむしの脂 肪酸の経時的変化

で最大に達した。しかし $20: 5 \omega 3$ などの $\omega 3$ HUFA の増加は認められなかった。先に渡辺らは, 淡水クロレ ラには $16: 4 \omega 3$ や $18: 3 \omega 3$ などの $\omega 3$ 脂肪酸が比較 的高濃度に含まれているのに, 岐阜水試で培養したクロ レラわむしには $\omega 3$ HUFA がほとんど存在しないとこ ろから,わむし体内では $16: 4 \omega 3$ や $18: 3 \omega 3$ は 20 : $5 \omega 3$ や $22: 6 \omega 3$ などの $\omega 3$ HUFA には転換されない のではないかと報告している。今回の結果からも, わむ しは淡水魚のような $\omega 3$ 脂肪酸の代謝経路 ${ }^{73)}$ をたない ものと推測している。

この乾燥粉末のクロレラで, $6 \mathrm{~h}$ 二次培養したわむし のし料効果は表-14にみられるように, 酵母わむしに比 べるとわずかに改善されたが, 海産クロレラによるもの と比較すると明らかに劣っていた。

このように $20: 5 \omega 3$ や $22: 6 \omega 3$ などの $\omega 3$ HUFA を含まない淡水産クロレラでわむしを培養しても, わむ

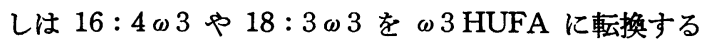


能力をもたないと 考えられることや，また過剩の 18 : $3 \omega 3$ は海産魚に好ましくないので，あゆのように EFA が不明な場合はともかく，生産されたわむしは海産魚に 対しては栄養価が低いものと考えられる。

クロレラの化学組成は種類や培養条件などによってか なり異なるので，乾燥クロレラなどで，わむしを培養す る場合にはクロレラの脂肪酸組成を充分に吟味してから 使用することが好ましい。

\section{7 酵母わむしの栄䓹欠陥と高度不飽和酸の 添加効果}

いままでの実験結果から，酵母わむしがクロレラわむ しに比べてし料効果の劣る理由，すなわち酵母わむしの

表-15 パン酵母, 油脂酵母及びそれらで培養した各わむしの 主な脂肪酸 (\%)

\begin{tabular}{|c|c|c|c|c|c|c|c|c|c|}
\hline \multirow{3}{*}{ 脂肪酸 } & \multicolumn{4}{|c|}{ パン 酵 母 } & \multicolumn{3}{|c|}{ 協和油脂酵母 } & \multirow{2}{*}{\multicolumn{2}{|c|}{ 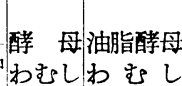 }} \\
\hline & \multirow{2}{*}{$\begin{array}{l}\text { 協和 } \\
1977\end{array}$} & \multirow{2}{*}{$\begin{array}{c}\text { A 社 } \\
1977\end{array}$} & \multicolumn{2}{|c|}{ B 社 } & \multicolumn{2}{|c|}{ 冷蔵 品 } & \multirow{2}{*}{$\begin{array}{c}\text { 冷涷品 } \\
1977\end{array}$} & & \\
\hline & & & 1977 & 1975 & 1976 & 1977 & & & \\
\hline $6: 0$ & 1.2 & 20.0 & 16.8 & 8.3 & 16.9 & 13.4 & 15.0 & $2 \sim 7$ & $10 \sim 1$ \\
\hline $16: 1$ & 14.2 & 27.2 & 32.8 & 38.2 & 5.0 & 6.6 & 6.1 & $26 \sim 27$ & $10 \sim 11$ \\
\hline $8:$ & & 7 & 4 & & 2.6 & 2.4 & 2.3 & $3 \sim 4$ & $2 \sim 3$ \\
\hline $18: 1$ & 38.0 & 26.1 & 28.5 & 43.9 & 16.0 & 16.4 & 15.5 & $26-30$ & $22 \sim 24$ \\
\hline $18: 2 \omega 6$ & 15.1 & 10.9 & 7.6 & 2.8 & 1.0 & 1.1 & 1.1 & $7 \sim 9$ & $2 \sim 4$ \\
\hline $8: 3 \omega 3$ & 6.4 & 3.2 & 1.8 & 0.5 & 0.9 & 0.8 & 0.8 & $3 \sim 4$ & $0.7 \sim 0$ \\
\hline $20: 1$ & 1.6 & 0.8 & Tr. & 0.2 & 8.4 & 9.1 & 9.2 & $1 \sim 2$ & $8 \sim 10$ \\
\hline $20: 4 \omega 6\}$ & & & & & 3.0 & 3.0 & 3.0 & $1 \sim 2$ & $3 \sim 4$ \\
\hline & & & & & & & & & \\
\hline $20: 5 \omega 3$ & & & & & 13.9 & 17.7 & 17.4 & $\sim 0.4$ & $9 \sim 12$ \\
\hline $22: 5 \omega 3$ & & & & & 1.0 & 1.0 & 0.9 & & $2 \sim 3$ \\
\hline $22: 6 \omega 3$ & & & & & 15.6 & 12.8 & 13.5 & & $7 \sim 9$ \\
\hline$\Sigma \omega 3$ & & & & & 33.5 & 34.7 & 34.5 & & $25 \sim 26$ \\
\hline
\end{tabular}

栄養欠陥がどこにあるのかほぼ明らかになったので，つ ぎにわむしの栄養価を改善することを試みた。すなわ ち, 従来のパン酵母に $20: 5 \omega 3$ のような $\omega 3$ HUFA を取り込ませた酵母（油脂酵母）でわむしを培養し，そ

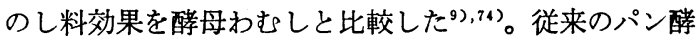
母と油脂酵母及びそれらで培養したわむしの脂肪酸組成 を表-15 に示した。従来のパン酵母は $\omega 3$ HUFA を含 まず，従って培養されたわむしも $\omega 3 \mathrm{HUFA}$ の含量が 著しく低い。一方，油脂酵母は $\omega 3$ HUFA 源として添 加したいか肝油に由来する $20: 5 \omega 3$ 及び $22: 6 \omega 3$ を 多量に含み, 総 $\omega 3$ 脂肪酸が $34 \%$ にも達する。この酵 母で培養した油脂酵母わむしは総 $\omega 3$ 脂肪酸が $25 \%$ に 達し, 前述したチグリオパスとアカルチアの中間的な值 を示した。

このような組成をもつ油脂酵母わむしのし 料効果を試験したところ，表-16 にみられる ように，油脂酵母わむしで飼育したし稚魚 は，まだい，くろだいいずれにおいても，成 長，生残率，活力テストなどで優れており， 酵母へ添加した $\omega 3$ HUFA の効果が明らか に認められた。また実用試験においても，ま だい，いしだいの量産に成功している75)。

まだい，いしだい及びくろだいで認められ た油脂酵母わむしのし料効果は，上述したよ うに $\omega 3$ HUFA によることは明らかであり， このことから酵母わむし給じによるし稚魚の 大量へい死などの原因は，主に酵母わむしの $\omega 3$ HUFA 不足にあるといえよう。

なお，最近渡辺ら ${ }^{70), 76) ~ は ， ~} \omega 3$ HUFA を 高濃度で含有するいか肝油等を乳化して直接

表-16 油脂酵母わむしのし料効果

\begin{tabular}{|c|c|c|c|c|c|c|c|}
\hline \multirow{2}{*}{ 試 験 魚 } & \multirow{2}{*}{ わむし } & \multirow{2}{*}{$\frac{\text { 実験開始時 }}{\text { 供 試 尾 数 }}$} & \multicolumn{2}{|c|}{ 実 験 終 了 時 } & \multirow{2}{*}{$\begin{array}{c}\text { 生 残 率 } \\
(\%, 6)\end{array}$} & \multirow{2}{*}{$\begin{array}{c}\text { 活力テスト } \\
\text { (q) }\end{array}$} & \multirow{2}{*}{ 摘 } \\
\hline & & & 全 長 $(\mathrm{mm})$ & 取り上げ尾数 & & & \\
\hline \multirow{4}{*}{ まだい } & 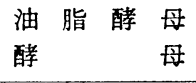 & $\begin{array}{c}30,000 \\
\prime \prime\end{array}$ & $\begin{array}{l}9.28 \pm 0.77 \\
7.44 \pm 0.78\end{array}$ & $\begin{array}{r}22,000 \\
4,000 \\
\end{array}$ & $\begin{array}{l}73.5 \\
13.0\end{array}$ & $\begin{array}{l}76.0 \\
12.5 \\
\end{array}$ & $\begin{array}{l}5 \text { 月 } 1 \text { 日多化 } \\
5 \text { 月 } 21 \text { 日終了 }\end{array}$ \\
\hline & $\begin{array}{l}\text { 油脂 酵 } \\
\text { ク } \\
\text { 口 } V \\
\mathrm{Y}_{12 \mathrm{C}^{* 1}}\end{array}$ & $\begin{array}{l}15,000 \\
12,000 \\
12,000\end{array}$ & $\begin{array}{r}9.18 \pm 0.87 \\
10.10 \pm 1.60 \\
9.25 \pm 1.24\end{array}$ & $\begin{array}{r}11,132 \\
5,200 \\
3,320\end{array}$ & $\begin{array}{l}74.2 \\
43.3 \\
27.7\end{array}$ & $\begin{array}{l}92.9 \\
91.7 \\
93.2\end{array}$ & $\begin{array}{l}6 \text { 月17日多化 } \\
7 \text { 月 } 8 \text { 日終了 }\end{array}$ \\
\hline & $\begin{array}{l}\text { (冷藏)油脂酵母 } \\
\text { (凍結)油脂酵母 } \\
\text { Y } 3 C^{* 1}\end{array}$ & $\begin{array}{c}24,000 \\
" \prime \\
"\end{array}$ & $\begin{array}{r}10.10 \pm 0.63 \\
9.78 \pm 0.65 \\
7.96 \pm 0.98\end{array}$ & $\begin{array}{l}8,700 \\
9,822 \\
9,524\end{array}$ & $\begin{array}{l}37.8 \\
42.7 \\
39.7\end{array}$ & $\begin{array}{l}96.3 \\
98.1 \\
80.7 \\
\end{array}$ & $\begin{array}{l}5 \text { 月 } 3 \text { 日ふ化 } \\
5 \text { 月 } 30 \text { 日終了 }\end{array}$ \\
\hline & 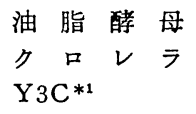 & $\begin{array}{c}15,000 \\
" \prime \\
"\end{array}$ & $\begin{array}{r}10.32 \pm 1.28 \\
9.78 \pm 1.11 \\
8.85 \pm 1.09\end{array}$ & $\begin{array}{l}7,586 \\
6,496 \\
2,638\end{array}$ & $\begin{array}{l}50.6 \\
43.3 \\
17.6\end{array}$ & $\begin{array}{l}88.2 \\
91.5 \\
55.8\end{array}$ & $\begin{array}{l}5 \text { 月25日ふ化 } \\
6 \text { 月21日終了 }\end{array}$ \\
\hline くろだい & $\begin{array}{lll}\text { 油 } & \text { 脂 } & \text { 酵 } \\
\text { 酵 } & & \end{array}$ & $\begin{array}{c}10,000 \\
\prime \prime\end{array}$ & $\begin{array}{r}10.91 \pm 0.94 \\
6.24 \pm 0.62\end{array}$ & $\begin{array}{r}6,550 \\
317\end{array}$ & $\begin{array}{r}65.5 \\
3.2\end{array}$ & $\begin{array}{l}95.5 \\
93.8\end{array}$ & $\begin{array}{l}5 \text { 月 } 3 \text { 日忍化 } \\
6 \text { 月 } 3 \text { 日終了 }\end{array}$ \\
\hline
\end{tabular}

*1 海産クロレラでそれぞれ $12 \mathrm{~h}$ 及び $3 \mathrm{~h}$ 二次培養した醉母わむし 
わむしの培地へ添加することによって，わむしに $\omega 3$ HUFA を取り込ませ, わむしの栄養価を改善できるこ とを報告している。油脂酵母による栄養価改善策を間接 法とすれば，後者は直接法といえるものである。

（昭和 56 年 12 月 3 日受理）

\section{文献}

1）渡辺 武, 荒川敏久, 北島 力, 藤田矢郎, 日水誌, 44, 985 (1978)

2）渡辺 武, 荒川敏久, 北岛 力, 福所邦彦, 藤田矢郎, 日水誌, 44, 979 (1978)

3）渡辺 武, 北島 力, 荒川敏久, 福所邦彦, 藤田矢郎, 日水誌, 44, 1109 (1978)

4) 渡辺 武, 大和史人, 北島 力, 藤田矢郎, 日水誌, 44, 1115 (1978)

5）渡辺 武, 荒川敏久, 北島 力, 福所邦彦, 藤田矢郎, 日水誌, 44, 1123 (1978)

6) T. Watanabe, Proc. 7 th Japan-Soviet Joint Symp. Aquaculture, Sept. 1978, p. 49 57

7）北島 力, 藤田矢郎, 大和史人, 米 康夫, 渡辺 武, 日水誌, 45, 469 (1979)

8）渡辺 武, 大和史人, 北島 力, 藤田榔, 米 康夫, 日水誌, 45, 883 (1979)

9) 今田 克, 影山百合明, 渡辺 武, 北島 力, 藤田矢郎, 米 康夫, 日水誌, 45, 955 (1979)

10) T. Watanabe, F. Oowa, C. Kitajima, S. Fujita' Bull. Japan. Soc. Sci. Fish., 46, 35 (1980)

11）北島 力, 荒川敏久, 大和史人, 藤田矢郎, 渡辺 武, 米 康夫, 日水誌, 46, 43 (1980)

12）北島 力, 吉田満彦, 渡辺 武, 日水誌, 46, 47 (1980)

13）岡 涁, 鈴木規夫, 渡辺 武, 日水誌, 46, 1413 (1980)

14）渡辺 武, 魚類の栄養と飼料, 新水産学全集 14, p. 81 110 , 恒星社厚生閣，東京 (1980)

15）藤田矢郎, 稚魚の摂餙と発育, 水産学シリーズ No. 8, 100 113, 恒星社厚生閣, 東京 (1975)

16）伏見 徹, 稚魚の摂慨と発育, 水産学シリーズ No. 8, 67 $\sim 83$ 恒星社厚生閣, 東京 (1975)

17）野沢卓䣲, 小林慎策, 北村佐三郎, 昭和 47 年度日本水産 学会春季大会講演要旨, p. 126

18）大原脩平, 野沢卓酸, 小林慎策, 北村佐三郎, 昭和 49 年 度日本水産学会春季大会講演要旨, p. 401

19）隅田征三郎, 尾脇満雄, 浦田勝喜, 昭和 48 年度能本水試 事業報告, 373 (1974)

20）北島 力, 耕田隆彦, 長崎水試研報, 2, 113 (1976)

21）福所邦彦, 長猗水試研報, 3, 152 (1977)

22）藤田矢郎, 日本ブランクトン学会報, 20,49 (1973)

23）鹿山光, 水産增殖, 20, 247 (1972)

24) N. Nicolaides, A.N. Woodall, J. Nutr., 78, 431 (1962)

25）東 秀雄, 金子德五郎, 石井清之助, 牛山宗弘, 杉橋孝夫, ビタミン, 30, 271 (1964)

26) J.D. Castell, R.O. Sinnhuber, J.H. Wales, D.J. Lee, J. Nutr., 102, 77 (1972)

27) J.D. Castell, R.O. Sinnhuber, D.J. Lee, J.H. Wales, J. Nutr., 102, 93 (1972)

28) J.D. Castell, D.J. Lee, R.O. Sinnhuber, J. Nutr., 102, 93 (1972)

29) T. Watanabe, F. Takashima, C. Ogino, Bull. Japan. Soc. Sci. Fsh., 40, 181 (1974)

30) T. Watanabe, I. Kobayashi, O. Utsue, C. Ogino,
Bull. Japan. Soc. Sci. Fish., 40, 387 (1974)

31) T. Watanabe, C. Ogino, Y. Koshiishi, T. Matsu= naga, Bull. Japan. Soc. Sci. Fish., 40, 493 (1974)

32）竹内俊郎, 渡辺 武, 日水誌, 43, 893 (1979)

33) T. Watanabe, T. Takeuchi, Bull.Japan. Soc. Sci. Fish., 42, 893 (1976)

34) T. Takeuchi, T. Watanabe, Bull. Japan. Soc. Sci. Fish., 42, 907 (1976)

35) T. Takeuchi, T. Watanabe, Bull. Japan. Soc. Sci. Fish., 43, 947 (1977)

36) T. Watanabe, O. Utsue, I. Kobayashi, C. Ogino, Bull. Japan. Soc. Sci. Fish., 41, 257 (1975)

37) T. Watanabe, T. Takeuchi, C. Ogino, Bull. Jas pan. Soc. Sci. Fish., 41, 263 (1975)

38）竹内俊郎, 渡辺 武, 日水誌, 43, 541 (1977)

39）竹内俊郎, 新井 茂, 渡辺 武, 新間弥一郎, 日水誌, 46, 345 (1980)

40) A. Kanazawa, S. Teshima, Bull. Japan. Soc. Sci. Fish., 46, 1353 (1980)

41）竹内俊郎, 佐藤秀一, 渡辺 武, 昭和 56 年度日本水産学 会秋季大会講演要旨, p. 93

42）竹内拨郎, 渡辺 武, 能勢健嗣, 日水誌, 45, 1319 (1979)

43）竹内拨郎, 渡辺 武, 昭和 55 年度日本水産学会秋季大会 講演要旨, p. 28

44）竹内俊郎, 養魚と飼料脂質, 水産学シリーズ No. 22, 2342, 恒星社厚生閣, 東京 (1978)

45）金沢昭夫，手島新一，小野和夫，昭和 52 年度日本水産学 会秋季大会講演要旨, p. 12

46）岡 涁, 水産增殖, 27, 202 (1980)

47) Y. Yone, M. Furuichi, Rept. Fish. Res. Lab. Kyushu Univ., 1, 49 (1976)

48) Y. Yone, M. Fujii, Bull. Japan. Soc. Sci. Fish., 41, 71 (1975)

49) Y. Yone, M. Fujii, Bull. Japan. Soc. Sci. Fish., 41, 79 (1975)

50）中山博文, 米 康夫, 昭和 52 年度日本水産学会春季大会 講演要旨, p. 189

51) M. Fujii, Y. Yone, Bull. Japan. Soc. Sci. Fish., 42, 583 (1976)

52）米 康夫, 高橋康之, 昭和 52 年度日本水産学会春季大会 講演要旨, p. 189

53）山田和雄, 小林邦男, 米 康夫, 昭和 52 年度日本水産学 会春季大会講演要旨, p. 85

54）山田和雄, 米 康夫, 昭和 52 年度日本水産学会春季大会 講演要旨, p. 190

55) C.B. Cowey, J.M. Owen, J.W. Adron, C. Midde= ton, Br. J. Nutr., 36, 479 (1976)

56) J.M. Owen, J.W. Adron, C. Middeton, C.B. Co wey, Lipids, 10, 528 (1975)

57）金沢昭夫，手島新一，小野和夫，昭和 52 年度春季大会講 演要旨, p. 85

58）伏見 徹, 広島水試研報，3，29（1972）

59）平田 満, 藤田忠勝, 水産増殖, 22, 120 (1974)

60）福所邦彦, 水産增殖, 21, 71 (1974)

61) J.F. Wickins, J. Exp. Mar. Biol., 10, 151 (1972)

62) A. Kanazawa, S. Tokiwa, M. Kayama, M. Hirata, Bull. Japan. Soc. Sci. Fish., 43, 1111 (1977)

63）手島新一, 養魚と飼料脂質, 水産学シリーズ No. $22,60-$ 77 , 恒星社厚生閣, 東京 (1978)

64）金沢昭夫, 手島新一, 鹿大水産学紀要, 26, 49 (1977)

65）昭和39-41年度指定試験研究，餌料生物大量培養技術研究 総合報告, 長猗水試 (1967) 
66) R.W. Morris, J. du Conseil, 20, 255 (1955)

67) T. Watanabe, R.G. Ackman, J. Fish. Res. Board Can., 31, 403 (1974)

68) 渡辺 武, 太田雅大, 北島 力, 藤田矢郎, 昭和 56 年度 日本水産学会秋季大会講演要旨, p. 345

69）藤田矢郎, 昭和 51 年度指定調査 研 究 報 告（長崎水試） (1976)

70）渡辺 武, 養魚用飼料油脂研究会, Bシリーズ, B9-1〜 B9-6 (1979)
71）渡辺 武, 養魚と飼料脂啠, 水産学シリーズ No. 22, 93111, 恒星社厚生閣, 東京 (1978)

72) 平山和次, 中村光治, Aquaculture, 8, 301 (1976)

73）渡辺 武, 化学々生物, 13, 289 (1975)

74) 渡辺 武, 海洋科学, 10, 740 (1978)

75）福所邦彦, 岩本 浩, 松岡正信, 今田 克, 藤田矢郎, 昭和 52 年度日本水産学会秋季大会講演要旨, p. 337

76) 渡辺 武, 田宮知則, 平田 满, 岡 涁, 北島 力, 藤田 矢郎, 昭和 56 年度日本水産学会秋季大会講演要旨, p. 78

\title{
プロスタグランジンの生化学
}

一一基礎と実験—

室田誠 逸 編

\author{
A 5 判 280 ページ \\ 東京化学同人発行 \\ 定価 4,600 円
}

プロスタグランジン (PG) は 1930 年代に von Euler らによって発見されたが，1960 年代に入り Bergström らにより 6 種類の PG の構造が決定され，それらの生合成経路，生理作用の解明の研究が盛んになった。1973 年の $\mathrm{PG}$ エンドペルオキシド $\left(\mathrm{PGG}_{2}, \mathrm{PGH}_{2}\right)$ の単離を契機とし, 従来の $\mathrm{PG}$ より短寿命にもかかわらずけた 違いの生物活性を有するトロンボキサン ( $\mathrm{TX})$, プロスタサイクリン $\left(\mathrm{PGI}_{2}\right)$ の発見及びぜん息の原因物質で あるロイコトリエン (LT) の構造決定など大きな発見が相次ぎ，ここ数年における PG 研究の進歩発展には目 を見張るものがある。しかし一方では PG の複雑多岐な作用及び生合成経路に関する膨大な数の発表論文が， 初心者に対しどのようにまとめて理解すべきか戸惑いを与える要因ともなっている。

このたびわが国における PG 研究の第一人者である室田誠冕博士を編者とする本書が刊行されたのは，まこ とに時機にかならといえる。本書は第 1 部基礎編, 第 2 部実験編の 2 部に分かれており，PG は初めてという方 方に PG の基礎知識と実験技術を伝えることを目的としている。第 1 部では, PG のあらまし, ホスホリパーゼ

(PLase) 反応, シクロオキシゲナーゼ反応, $\mathrm{PGI}_{2}, \mathrm{LT}, \mathrm{PG}$ の医薬への応用, 第2 部ではシクロオキシゲナー ゼ代謝物の抽出・分離・同定・生合成活性の測定, PLase 活性の測定, リポキシゲナーゼ代謝物の生合成活性の 測定, ラジオイムノアッセイ, ガスクロマトグラフィー/質量分析法, 生合成酵素の調整法とその応用, $\mathrm{PGI}_{2}$ の 化学合成について述べているが，ここ数年間に発見された $\mathrm{PGG}_{2}, \mathrm{PGH}_{2}, \mathrm{TX}, \mathrm{PGI}_{2}, \mathrm{LT}$ の生合成及び生理作 用に重点をおいてまとめていることが本書の特徴といえる。ゆえに PG 関連物質の化学合成については紙数が少 ないのでもの足りなく感じるかもしれない。全体をみわたすと図表が多く，図では漫画風に示すなど読者が理解 しやすいよう配虑しており, 読みやすい本といえる。引用文献も豊富にあり PG 領域の最新の基礎知識を得るた めの必読の書といえる。付録として PG の分子量, 安定性, 略語, PG 関連試薬の販売元, PG 溶液の濃度計算 なども揭載されているが，これは初心者にとって大いに役立つと思う。なおアラキドン酸と共に PG 生合成の前 駆体不飽和脂肪酸である「イコサペンタエン酸」の旧称（エイコサペンタエン酸）を用いているが第2 版では訂 正を望みたいと思う。 (三浦洋四郎 : 帝京大学医学部生化学) 